\title{
Dopaminergic Regulation of Transcription Factor Expression in Organotypic Cultures of Developing Striatum
}

\author{
Fu-Chin Liu, Hiroshi Takahashi, ${ }^{a}$ Ronald D. G. McKay, ${ }^{b}$ and Ann M. Graybiel \\ Massachusetts Institute of Technology, Department of Brain and Cognitive Sciences, Cambridge, Massachusetts \\ 02139
}

\begin{abstract}
Dopamine is a major neurotransmitter in neural systems innervating the striatum, and dopamine receptors are expressed during early pattern formation in the developing striatum. To test for the functional responsiveness of developing striatal neurons to dopaminergic stimulation, we established an organotypic slice culture of newborn rat striatum. We analyzed the effects of dopamine receptor agonists and of adenylate cyclase and protein kinase activation on striatal neurons by measuring the induction of Fos-like and Fra-like proteins in the cultured striatum. Foslike and Fra-like proteins were induced in striatal neurons by activation of D1-like dopamine receptors but not by activation of D2-like receptors. The induction of Fos-like protein was mainly in striosomes and a medial compartment next to the ventricular zone, whereas Fra-like protein was induced in the striatal matrix as well. cAMP analogs and forskolin induced widespread expression of both Fos-like and Fra-like proteins. Our findings thus suggest that neurons of developing striosome and matrix compartments not only have different functional coupling of D1-like receptors to adenylate cyclase, but also have distinct maturational programs for dopaminergic regulation of individual transcription factors. Finally, despite evidence that protein kinase was involved in the induction of Fos-like protein, experiments with kinase inhibitors suggested that the induction of Fos-like protein had unusual pharmacological characteristics and raised the possibility that a novel protein kinase A-like molecule may have been involved in the induction. The cultured striatal slice preparation should
\end{abstract}

\footnotetext{
Received June 10, 1994; revised Sept. 28, 1994; accepted Oct. 3, 1994.

This work was supported by NIH 1 R01 HD28341 and by Grant 3244A

from The Council for Tobacco Research-U.S.A., Inc. to A.M.G. We are grateful to Dr. J. Weinstock and SmithKline Beecham Pharmaceuticals for providing SKF-81297, to Dr. M. J. Iadarola for providing his Fos/Fra antiserum, to Drs. P. Greengard, E. L. Gustafson, and H. Hemmings for providing DARPP-32 antibody, to Dr. P. C. Emson for providing calbindin- $D_{28 \mathrm{kD}}$ antiserum, to Dr. R. $M$. Nitsch for help with the assay of ${ }^{35} \mathrm{~S}$-methionine incorporation, and to $\mathrm{Dr}$. B. Madras for advice on the use of SKF-81297. We thank Miss D. Major for her invaluable help with the histology and Mr. H. F. Hall, who is responsible for the photography. F.-C.L. was supported by a postdoctoral fellowship from the Hereditary Disease Foundation.

Correspondence should be addressed to Fu-Chin Liu, Ph.D., Massachusetts Institute of Technology, Department of Brain and Cognitive Sciences, E25618, 45 Carleton Street, Cambridge, MA 02139

aPresent address: Laboratory of Histochemistry, Mitsubishi Kasei Institute of Life Sciences, 11 Minami Ooya, Machida-shi, Tokyo-194, Japan.

"Present address: Laboratory of Molecular Biology, National Institute of Neurological Disorders and Stroke, National Institutes of Health, Building 36, Room 3DO2, 9000 Rockville Pike, Bethesda, MD 20892.

Copyright $(1995$ Society for Neuroscience $0270-6474 / 95 / 152367-18 \$ 05.00 / 0$
}

provide a valuable tool for analyzing the molecular determinants of striatal development and function.

[Key words: basal ganglia, striosome, c-fos, immediateearly gene, dopamine D1 receptor, cAMP, kinase, development]

Dopamine, as the principal neurotransmitter in neural tracts leading from the midbrain to the forebrain, influences functions ranging from motor and cognitive performance to addictive behavior. In addition, dopamine may also regulate neuronal development (Lankford et al., 1988; McCobb et al., 1988; Reinoso et al., 1993; Swarzenski et al., 1994). Bridging between dopamine and its functional effects are multiple dopamine receptor subtypes whose differential linkage to intracellular messenger systems is a matter of intense study (Sibley et al., 1993). Activation of dopamine receptors not only acutely affects the physiology of neurons, but can result in long-term alterations in gene expression in activated neurons (Graybiel, 1990; Gerfen, 1992b). This evidence for transcriptional regulation is of interest for work on neuroplasticity and development in dopaminergic systems.

Among the genes that have been implicated in coupling such receptor-mediated effects to long-term changes are immediateearly genes, including those of the fos-jun family, whose protein products exert combinatorial control over downstream gene expression (Sheng and Greenberg, 1990). Stimulation of dopamine receptors has been found to regulate such genes in vivo in subsets of striatal neurons both in adult and in embryonic and neonatal rodents (Robertson et al., 1989; Graybiel et al., 1990; Young et al., 1991; Berretta et al., 1992; Cole et al., 1992; Moratalla et al., 1992, 1993; Nguyen et al., 1992; Paul et al., 1992; Zhang et al., 1992; Dilts et al., 1993; LaHoste et al., 1993; Bronstein et al., 1994; Fusco et al., 1994; for review, see Grzanna and Brown, 1993). However, such in vivo experiments are not appropriate for determining whether the regulatory effects of dopamine receptor stimulation are direct downstream actions of dopamine receptors expressed in the striatum, and do not permit analysis of the signaling cascades.

To address these questions of signaling process in the striatal neurons, we developed an organotypic slice culture of striatum from newborn rat brains. With such organotypic striatal slice cultures, we analyzed the functional responses of developing striatal neurons to dopaminergic challenges. We chose the postnatal day $(\mathrm{P}) 0$ striatum for study, because most striatal neurons have been born, and the main tissue of the striatum (the striosomes and matrix) have been formed, but much of the neurochemical and morphological differentiation of the striatum is yet to be completed. As this differentiation occurs in the presence 

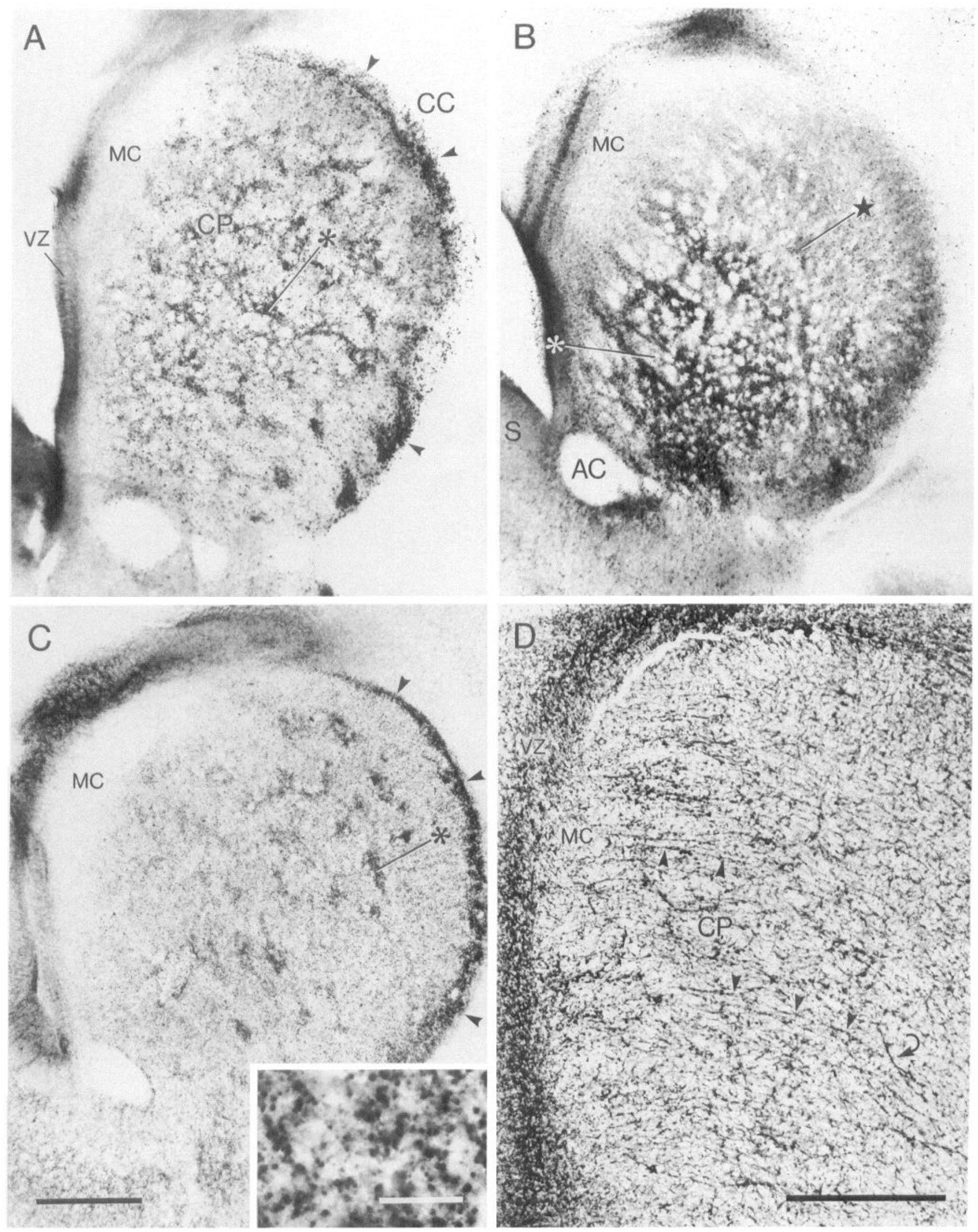

Figure 1. Neuronal phenotypes in $3 \mathrm{~d}$ striatal slice cultures. Photographs illustrate striatal slices cultured for $3 \mathrm{~d}$ in vitro and immunostained for different striatal-enriched antigens. A, DARPP-32-like immunostaining showing many DARPP-32-rich cell clusters (developing striosomes, example at asterisk) and a DARPP-32-positive lateral rim (arrowheads) in the cultured caudoputamen (CP). Very little DARPP-32-like staining is present 
of an already dense dopaminergic innervation and dopamine receptor expression (Specht et al., 1981; Voorn et al., 1988; Murrin and Zeng, 1989; Sales et al., 1989), we hoped to identify striatal neurons responsive to dopamine receptor stimulation, and to characterize the responses.

We studied the expression of fos- and fra-like gene products in neurons of the striatal slices following stimulation of D1-like and D2-like receptors, and following activation and inactivation of second messengers identified with D1 and D2 signaling pathways Because the cultured slices maintained developing striosome and matrix compartments, we were further able to determine whether differential induction of fos- and fra-like genes occurred in these two compartments, which have different developmental schedules, express different combinations of neurotransmitter-related substances and develop different connections with other brain regions that tend to link striosomes to limbic and matrix to sensorimotor circuits (for review, see Graybiel, 1990, 1993a; Gerfen, 1992b).

Our results indicate that transcription factors of the Fos-Jun family can be induced in cultured striatal neurons by stimulation of dopamine receptors, that this induction is mediated through D1-like dopamine receptors coupled to cAMP-adenylate cyclase and protein kinases, and that developing striosome and matrix neurons respond differently and express different fos family genes in response to stimulation of D1-like receptors. In addition, a medial compartment adjacent to the ventricular zone is distinguished in the experiment. This slice culture system should provide a powerful adjunct to in vivo work on the regulation of gene expression in the developing striatum.

\section{Materials and Methods}

Preparation of organotypic slice cultures. The organotypic slice culture method of Stoppini et al. (1991) was adapted for use with slight modifications (Liu et al., 1993). Newborn pups of Sprague-Dawley rats (Taconic Farms, Germantown, NY) were anaesthetized by hypothermia, and the brains were removed following decapitation. The brain tissue was embedded in $4 \%$ low melting temperature agarose (FMC BioProducts, Rockland, ME) dissolved in Gey's Balanced Salt Solution (GIBCO-Bethesda Research Labs, Grand Island, NY) supplemented with $5.5 \mathrm{mg} / \mathrm{ml}$ glucose, and then was cut on a vibratome into $300 \mu \mathrm{m}$ thick coronal slices. The agarose and the pia mater were removed from each slice, and the two hemispheres were separated by cutting through the midline of the forebrain. In some slices, part of the dorsomedial neocortex was cut off to prevent its later curling, which led to tissue damage and cell death in the slices. Slices were cultured on top of 0.4 $\mu \mathrm{m}$ microporous transparent biopore membranes in $30 \mathrm{~mm}$ culture plate inserts (Millicell-CM, Millipore, Bedford, MA). All slices from a single hemisphere of a single brain were cultured together in an individual insert. The inserts were placed in six-well culture dishes. Each well was supplied with $1 \mathrm{ml}$ of SF21 serum-free medium (Segal et al., 1992), which is a modification of B18 serum-free medium (Brewer and Cotman, 1989). The cultures were incubated in a humidified incubator at $33^{\circ} \mathrm{C}$ with $5 \% \mathrm{CO}_{2}, 95 \%$ air.

All the experimental procedures involving animals were approved by the Committee on Animal Care of the Massachusetts Institute of Technology.
Application of dopamine receptor agonists and antagonists. Striatal slices werc typically maintaincd in culturc for $3 \mathrm{~d}$ before application of pharmacologic agents to the culture medium. Short-term cultures were also studied. Incubation with drugs were carried out for 2.5-3 hr. For all experiments, vehicle incubations were run in parallel as controls. The dopamine agonists and antagonists tested included the full D1selective agonist, SKF-81297 $\mathrm{HCl}(100 \mathrm{nM}$, kindly provided by $\mathrm{Dr}$. Joseph Weinstock of SmithKline Beecham Pharmaceuticals, King of Prussia, PA; Nielsen et al., 1989; Andersen and Jansen, 1990); the partial D1-selective agonist, R(+)-SKF-38393 HCl [1 $\mu \mathrm{M}$; Research Biochemicals Inc. (RBI), Natick, MA; Andersen and Jansen, 1990]; the D2-selective agonist, $\mathrm{R}(-)$-quinpirole $\mathrm{HCl}(1$ and $10 \mu \mathrm{M}$; RBI; Nagahama et al., 1986); the nonselective dopamine receptor agonist apomorphine (1 and $10 \mu \mathrm{M}$; Sigma, St. Louis, MO); the D1-selective antagonist, $\mathbf{R}(+)-\mathrm{SCH}-23390 \mathrm{HCl}(1$ and $10 \mu \mathrm{M}$; RBI; Hyttel, 1983); the D2-selective anlagonist, metoclopranide (10 and $100 \mu \mathrm{M}$; Signa); and corresponding vehicles. The vehicle for dissolving SKF-81297 was $0.6 \%$ ethanol and $0.2 \% \mathrm{HCl}$ in $0.9 \%$ saline containing $1 \mathrm{mM}$ EDTA and $0.01 \%$ ascorbic acid. SKF-38393, SCH-23390, quinpirole and metoclopramide were dissolved in sterile $0.9 \%$ saline. Apomorphine was dissolved in $0.9 \%$ saline containing $0.5 \%$ ethanol. For receptor blocking experiments, the cultures were preincubated with R(+)-SCH-23390 (1 and $10 \mu \mathrm{M})$ or metoclopramide $(10$ and $100 \mu \mathrm{M})$ for $45 \mathrm{~min}$ to $2 \mathrm{hr}$ before the addition of dopamine agonists. When possible, stimulation and blocking or vehicle control treatments were done in pairs on the two hemispheres of individual brains. All other controls were carried out on hemispheres from littermate brains.

Application of protein kinase activators and inhibitors. Striatal slices cultured for $3 \mathrm{~d}$ in vitro were incubated for 2.5-3 hr with the cAMP analogs, dibutyryl-cAMP ( 1 and $3 \mathrm{mM}$; Sigma) and Sp-cAMPS (100 $\mu \mathrm{M}, 1 \mathrm{mM}$; RBI); the adenylate cyclase activator, forskolin $(10 \mu \mathrm{M}$; $\mathrm{RBI}$ ); the forskolin analog, 1,9-dideoxy-forskolin (10 $\mathrm{M}$; RBI), which does not stimulate adenylate cyclase; the protein kinase $\mathrm{C}$ activator, phorbol 12-myristate 13-acetate (PMA; 40.5, 81, 162, 486, and $810 \mathrm{nM}$, $1.62,16.2$, and $96.6 \mu \mathrm{M}$; RBI); the PMA analog. $4 \alpha-\mathrm{PMA}(1.62,16.2$, and $96.6 \mu \mathrm{M}$; RBI), which does not stimulate protein kinase $C$; or their vehicle, dimethyl sulfoxide. For protein kinase inhibitor experiments, the striatal slices were preincubated with the protein kinase inhibitors, Rp-cAMPS (100 $\mu \mathrm{M}, 1 \mathrm{mM}$; RBI); H7 (50 and $100 \mu \mathrm{M}$; RBI), H8 (50 and $100 \mu \mathrm{M}$; RBI), H89 $(30,60,90,120,300$, and $600 \mu \mathrm{M}$; Seikagaku, Rockville, MD), H85 (30 and $600 \mu \mathrm{M}$; Seikagaku), or KN62 (30 $\mu$; Seikagaku), or with the calmodulin inhibitor, W7 (100 $\mu \mathrm{M}$; RBI), for 1 hr before the application of SKF-81297 (100 nM) or forskolin $(10 \mu \mathrm{M})$. The doses listed were determined in preliminary experiments. Forskolin, 1,9-dideoxy-forskolin, PMA, 4 $\alpha$-PMA, H7, H8, H89, H85, KN62, and W7 were dissolved in dimethyl sulfoxide. Dibutyryl-cAMP, Sp-cAMPS, and Rp-cAMPS were dissolved in distilled water.

For comparison with the kinase inhibition experiments, other $3 \mathrm{~d}$ striatal slice cultures were incubated with the protein synthesis inhibitor, cycloheximide (10 and $50 \mu \mathrm{M}$, in sterile $0.9 \%$ saline; Sigma) for $1 \mathrm{hr}$ before the application of SKF-81297 (100 nM).

Incorporation of 5-bromo-3'-deoxyuridine. Striatal slices cultivated for $3 \mathrm{~d}$ in vitro were incubated with 5-bromo-3'-deoxyuridine (BrdU, $10 \mu \mathrm{M}$ ) for $3 \mathrm{hr}$, and were then fixed in $70 \%$ ethanol in $50 \mathrm{~mm}$ glycine buffer ( $\mathrm{pH} \mathrm{2.0)}$ ) for $1 \mathrm{hr}$ at $-20^{\circ} \mathrm{C}$. The immunostaining for BrdU was carried out according to the manufacturer's protocol (Detection kit II, Boehringer Mannheim Biochemica, Indianapolis, IN).

Immunostaining. After incubation, the slices were fixed in ice-cold 4\% paraformaldehyde in $0.1 \mathrm{M}$ phosphate buffer ( $\mathrm{PB}, \mathrm{pH} 7.4)$ for $1 \mathrm{hr}$. For immunostaining, the slices were successively rinsed $(4 \times 10 \mathrm{~min})$ with $\mathrm{PB}$ containing $0.1 \%$ azide, were washed with $1.5 \% \mathrm{H}_{2} \mathrm{O}_{2}, 3 \%$ methanol in $0.01 \mathrm{M}$ phosphate-buffered saline (PBS) containing $0.2 \%$

$\leftarrow$

in the medial compartment $(M C)$ adjacent to the ventricular zone $(V Z)$. The dark staining at the ventricular edge of the tissue is nonspecific staining of diffuse noncellular immunostaining products and occurred in the ventricular zone of other slices stained for other antigens $(B$, $C$, and Figs. 2$4,7) . B$, Cultured striatum immunostained for calbindin- $\mathrm{D}_{28 \mathrm{kD}}$. Calbindin- $\mathrm{D}_{28 \mathrm{kD}}-$-like immunoreactivity is mainly ventral and is in the matrix. Asterisk indicates a calbindin- $\mathrm{D}_{28 \mathrm{kD}}$-poor striosome. A few dorsal calbindin- $\mathrm{D}_{28 \mathrm{kD}}$-rich patches (example at star) also appear, and these have been shown to represent transiently stained striosomes (see Liu and Graybiel, 1992a,b). The medial compartment is not stained. $C$, TH-like immunostaining of a cultured slice showing that many TH-positive patches (dopamine islands, corresponding to developing striosomes; example at asterisk) as well as a strongly TH-positive lateral rim (arrowheads) are present in the cultured striatum. Inset shows higher magnification of the central part of the THpositive striosome indicated by the asterisk in $C$. D. Rat.401 immunostaining of a cultured striatal slice showing arching Rat.401-positive radial glial fibers (examples at arrowheads) extending through the caudoputamen $(C P)$. The Rat 401 antibody also stained blood vessels (example at curved arrow). $A C$, Anterior commissure; $C C$, corpus callosum; $S$, septum. Scale bar: $A-C$ (in $C$ ) and $D, 500 \mu m$; inset in $C, 20 \mu m$. 
Triton X-100, and were incubated in 5\% normal goat serum in PBS for $1 \mathrm{hr}$, with several washes in PBS intervened between the steps.

Primary incubations were carried out with 1:200 rabbit polyclonal anti-c-Fos antiserum (Oncogene Science Inc., Uniondale, NY, Ab2 OGS, lot 3920501), 1:10,000-20,000 mouse monoclunal anti-dopamine- and adenosine $3^{\prime}: 5^{\prime}$-monophosphate-regulated phosphoprotein (DARPP-32) antibody (kindly provided by Drs. E. L. Gustafson and P. Greengard of The Rockefeller University and H. Hemmings of The New York Hospital-Cornell Medical Center), 1:1000 rabbit polyclonal anticalbindin- $\mathrm{D}_{28 \mathrm{kD}}$ antiserum (kindly provided by Dr. P. C. Emson of Institute of Animal Physiology, Barbaraharm, Cambridge, U.K.), 1:1000 mouse monoclonal anti-tyrosine hydroxylase (TH) antibody (Incstar, Stillwater, MN, lot 8930030 ), 1:5000 rabbit polyclonal anti-Fos/Fosrelated antigens (Fra) antiserum (kindly provided by Dr. M. J. Iadarola of the National Institute of Dental Research, National Institutes of Health, Bethesda, MD; batch F2 prep 1; Young et al., 1991), 1:1 mousc monoclonal anti-nestin antibody (Rat.401), 1:400 mouse monoclonal anti-microtubule-associated protein 2 (MAP-2) (Boehringer Mannheim Biochemica, Indianapolis, IN), 1:400 rabbit polyclonal anti-glial fibrillary acidic protein (GFAP) (Sigma, St. Louis, MO), and 1:150 mouse monoclonal anti-proliferating cell nuclear antigen antibody (PCNA, Santa Cruz Biotechnology, Santa Cruz, CA). Incubation solutions contained $0.4 \%$ Triton $X-100,1 \%$ normal rat serum, $1 \%$ normal goat serum (for OGS Fos, Iadarola Fos/Fra, calbindin- $D_{28 \mathrm{kD}}$ and GFAP antisera) or normal horse serum (for DARPP-32, TH, Rat.401, MAP-2, and PCNA antibodies) and $0.1 \%$ azide in PBS. Slices were incubated at room temperature overnight, and were then processed for immunocytochemistry by the avidin-biotin-peroxidase complex (ABC) method as described elsewhere (Hsu et al., 1981; Liu et al., 1991). A number of DARPP-32 immunostained slices were cryoprotected with $20 \%$ glycerul in $0.1 \mathrm{M}$ $\mathrm{PB}$ containing $0.1 \%$ azide, and were then cut into $20 \mu \mathrm{m}$ thick sections on a freezing microtome.

Controls for the specificity of OGS Fos-like immunostaining were carried out by incubating slices with OGS anti-Fos antiserum preabsorbed with the peptide to which the antiserum was raised (Oncogene Science Inc., S-14-C, lot 923802), and for other antisera and antibodies, including the Iadarola Fos/Fra antiserum, by omission of the primary antibody in the staining process. The findings described for Fos-like and Fos/Fra-like protein expression refer strictly to immunodetectable proteins observed with the OGS (Fos-like) and Iadarola (Fos/Fra-like) antiscra uscd.

Double staining for Fos-like immunoreactivity and DARPP-32-like or PCNA-like immunoreactivity was carried out by the ABC method (Batchelor et al., 1989). Slices were first stained for Fos-like protein (OGS antiserum) with diaminobenzidine (DAB)/nickel intensification. To deplete endogenous peroxidase activity and to block excessive biotin binding sites from the first staining, the slices were then treated with $0.6 \% \mathrm{H}_{2} \mathrm{O}_{2}$ in $0.1 \mathrm{M}$ Tris buffered-saline (TBS) for $45 \mathrm{~min}, 6 \mu$ l biotin/ $\mathrm{ml}$ TBS for $30 \mathrm{~min}, 6 \mu \mathrm{l}$ avidin $/ \mathrm{ml}$ TBS for $30 \mathrm{~min}$, and $5 \%$ normal horse serum in TBS for $1 \mathrm{hr}$, with several TBS rinses in between. Slices were then incubated in 1:20,000 mouse monoclonal anti-DARPP-32 antibody or 1:150 mouse monoclonal anti-PCNA antibody at room temperature overnight, and were processed for immunostaining with DAB as chromogen. Double immunofluorescence staining was also carried out for Fos-like protein and DARPP-32. The slices were incubated overnight in a mixture of OGS anti-Fos antiserum and anti-DARPP-32 antibody at room temperature, and were then incubated in a mixture of secondary antisera containing 1:100 donkey anti-rabbit conjugated with Texas red (Jackson ImmunoResearch Laboratories Inc., West Grove, PA) and 1:100 donkey anti-mouse conjugated with FITC (Jackson ImmunoResearch Laboratories) for $3 \mathrm{hr}$. Patterns of immunofluorescence were studied with a laser confocal microscope (Bio-Rad, MRC600 , Hercules, C.A) to determine whether colocalization of antigens occurred in individual striatal neurons.

Assay for protein synthesis following protein kinase inhibition. ${ }^{35} \mathrm{~S}-$ Methionine incorporation was mcasured to estimate the protein synthesis in slices subjected to protein kinase inhibitors, as this treatment has been found to reduce protein content in other in vitro systems (Klymkowsky, 1988). Triplicates of striatal slice cultures maintained for $3 \mathrm{~d}$ in vitro were rinsed twice in methionine-free culture medium and were preincubated in methionine-free culture medium with one of three protein kinase inhibitors: $\mathrm{H} 7(50 \mu \mathrm{M}), \mathrm{H} 8(100 \mu \mathrm{M})$ or $\mathrm{H} 89(600 \mu \mathrm{M})$ for $1 \mathrm{hr}$. Slices were then incubated for $3 \mathrm{hr}$ in the same methionine-free medium to which SKF-81297 (100 nM) and ${ }^{35} \mathrm{~S}$-methionine $(10 \mu \mathrm{Ci} /$ $\mathrm{ml}$, New England Nuclear, Boston, MA) were added. Control striatal slices were incubated with ${ }^{35}$ S-methionine and SKF-81297 without preincubation with kinase inhibitor. Following incubation, the slices were rinsed three times in $0.1 \mathrm{M}$ PBS, were lysed with $10 \%$ trichloroacetic acid and were spun down at 13,000 $\times g$ for $15 \mathrm{~min}$. The pellets were resuspended in $0.1 \mathrm{~N} \mathrm{NaOH}$ and were sonicated briefly. The radioactivity in $10 \mu$ l aliquots of each sample was determined by liquid scintillation counting. Another $10 \mu \mathrm{l}$ aliquot of each sample was used for protein assay to determine the quantity of total protein present in each sample (BCA Protein Assay, Pierce, Rockford, IL). The incorporation of ${ }^{35} \mathrm{~S}$-methionine in each sample was then normalized for protein content.

\section{Results}

\section{Expression of neuronal phenotypes and developing}

compartmentation in organotypic cultures of neonatal striatum The cultured forebrain slices contained tissue of the caudoputamen and cerebral cortex and, depending on the anteroposterior level, of other regions including the nucleus accumbens, olfactory tubercle, globus pallidus, and septum (Figs. 1, 2C). Slices were routinely cultivated for $3 \mathrm{~d}$ in vitro before treatment, at which time there was minimal constitutive expression of Foslike protein in the striatum (see below). To assess the general status of neuronal survival in the organotypic cultures, sets of slices cultivated for $3 \mathrm{~d}$ were stained for microtubule-associated protein 2 (MAP-2), a neuronal marker (Garner et al., 1988). There were numerous MAP-2-positive neurons distributed through the striatum and other regions of the cultured forebrain slices (data not shown).

As an assay for the expression of striatal neuronal phenotypes and compartmentation in the cultured striatum, other slices were stained for DARPP-32 or for calbindin- $\mathrm{D}_{2 \mathrm{sk}}$, two molecules expressed by medium spiny neurons and previously identified in the rat striatum as neuronal markers for, respectively, developing striosomes (DARPP-32) and matrix (calbindin- $\mathrm{D}_{28 \mathrm{kD}}$ ) (Foster et al., 1987; Liu and Graybiel, 1992a; for adult data, see Walaas and Greengard, 1984; Gerfen et al., 1985). There were many DARPP-32-positive and calbindin- $\mathrm{D}_{28 \mathrm{kD}}$-positive neurons in the cultured striatum (Fig. $1 A, B$ ), and the differential distributions of the DARPP-32 and calbindin- $\mathrm{D}_{28 \mathrm{kD}}$ immunostaining in the slices were similar to those in the developing striatum in vivo. These results demonstrated not only an excellent neuronal survival but also a developing compartmentation in the cultured striatum.

\section{Preliminary evaluation of neuronal survival rate in $3 d$ striatal slice cultures}

Due to the limited optical resolution in microscopy, we could not correctly assess the whole population of surviving neurons throughout the depth of the slices. We therefore developed a technique by which $3 \mathrm{~d}$ striatal slice cultures were first wholemount immunostained for DARPP-32, and were then sectioned into a series of thin sections $(20 \mu \mathrm{m})$. By reconstruction of the consecutive thin sections derived from individual slices, we found that the thickness of whole-mount immunostained slices was ca. $200-240 \mu \mathrm{m}$. Even assuming that the immunostaining process led to tissue shrinkage, this finding suggested that the slices, originally cut at thickness of $300 \mu \mathrm{m}$, had flatten into thinner slices during the course of the $3 \mathrm{~d}$ cultivation in vitro. Within this thickness, patches of DARPP-32-positive striatal neurons were evident across a depth of ca. 140-160 $\mu \mathrm{m}$, including all but the top and bottom surfaces of the slices. Thus, there was penetration of antibody through the slices, but superficial zones lacking cellular DARPP-32 staining. We used the thickness within which DARPP-32-positive neurons were found 
as an estimate of the region of cell survival, and the DARPP32-positive neurons as a rough indicator of neuronal survival in general. With these estimates, we judged that the neuronal survival rate in the slices was ca. $60-70 \%(140 / 240 \mu \mathrm{m}$ to $140 / 200$ $\mu \mathrm{m})$. Correspondingly, the numbers of dead and dying cells in the slices could be inferred to be in the range of $30-40 \%$.

\section{Persistence of tyrosine hydroxylase-positive dopamine islands in 3 d striatal slice cultures}

To determine whether dopamine-containing fibers persisted in the striatum after $3 \mathrm{~d}$ in vitro, we stained a series of the $3 \mathrm{~d}$ slice cultures for TH-like immunoreactivity. As shown in Figure $1 C$, patches of intense TH-like immunoreactivity were distributed through the cultured neonatal striatum in a pattern similar to that of the so-called dopamine islands, which are known to correspond to developing striosomes (Olson et al., 1972; Tennyson et al., 1972; Graybiel, 1984; Moon Edley and Herkenham, 1984; Murrin and Ferrer, 1984; van der Kooy, 1984). The THlike immunostaining of the islands was most intense dorsally and laterally, and there was a rim of strong immunostaining along the lateral edge of the caudoputamen. However, the THlike immunoreactivity in the striatal slices did not appear in the normal fibrous pattern typical of that in the newborn rat. The staining (Fig. $1 C$, inset) was associated mainly with small $\mathrm{TH}$ immunoreactive granules and puncta, presumably representing degenerating TH-immunoreactive fiber and terminals of the dopamine-containing mesostriatal pathway.

\section{Presence of proliferative ventricular zone, neuronal and glial} precursor cells, radial glia and astrocytes in cultured striatum

The status of mitotic activity in the ventricular zone of $3 \mathrm{~d}$ cultured slices was assayed by incubating the slices with the thymidine analog, 5-bromo-3'-deoxyuridine (BrdU), which labels proliferating cells. Many BrdU-positive cells were present in the ventricular zone (Fig. $3 A$ ). This result was confirmed by immunostaining for proliferating cell nuclear antigen (PCNA), an independent marker for mitotic cells; many PCNA-positive cells were present in the ventricular zone (data not shown).

The survival of precursor cells of neurons and glial cells was assessed in $3 \mathrm{~d}$ slice cultures by immunostaining for Rat.401 (nestin) (Hockfield and McKay, 1985; Lendahl et al., 1990). Many Rat.401-positive cells were present in the ventricular zone, and there were Rat.401-positive cells in the striatum (and neocortex) as well (Fig. 1D). Remarkably, the architecture of Rat.401-positive radial glial cells was well preserved. An array of radial glial fibers stretched from the ventricular zone across the striatum proper toward the lateral edge of the cultured stria- tum, as found in neonatal rat striatum in vivo (Liu and Graybiel, 1992b).

Three-day striatal slices were also stained for glial fibrillary acidic protein (GFAP) to study the distribution of astrocytes in slices. Numerous GFAP-positive astrocytes with extended, well differentiated processes were present in the striatum proper. By contrast, such cells were rare or absent in the medial compartment. Instead, this compartment contained intensely stained GFAP-positive cells with a few short processes and many small weakly GFAP-positive cells without stained processes (data not shown).

\section{Basal expression of Fos-like protein in striatal slice cultures} as a function of time in vitro

The basal levels of expression of Fos-like protein were assessed in control slices cultivated in vitro from times varying from 4 hr $(n=3)$ to $1 \mathrm{~d}(n=3), 2 \mathrm{~d}(n=3)$, or $3 \mathrm{~d}(n=7)$, with final $2.5-3 \mathrm{hr}$ exposures to $0.9 \%$ saline or to the vehicle for apomorphine $(0.5 \%$ ethanol in $0.9 \%$ saline). The slices were stained for Fos-like immunoreactivity with the polyclonal OGS anti-Fos antiserum. For simplicity, we use the terms, "Fos" and "Fos-like", in the following text strictly to refer to Fos-like antigens recognized by the OGS anti-Fos antiserum. We also use the term, "D1-like receptors," to refer to the subfamily of D1 $\left(D_{1 A}\right)$ and D5 $\left(D_{1 B}\right)$ receptors, and the term, "D2-like receptors", to refer to the subfamily of D2, D3, and D4 receptors (see below).

In slices cultivated for $4 \mathrm{hr}$, diffuse nuclear Fos-like immunostaining was broadly distributed throughout the tissue, including the striatum and the cerebral cortex (Fig. 2A). In addition, there were a few very weakly stained clusters of Fos-positive nuclei in the lateral part of the caudoputamen. For this reason, we did not carry out the main series of experiments in such acutely prepared slice cultures. However, we did test the capacity of dopamine receptor agonists to induce Fos-like protein at these shorter times as described below (Fig. $2 A^{\prime}$ ).

After $1 \mathrm{~d}$ in vitro, clusters of weakly stained Fos-positive cells were still evident in the lateral striatum of the vehicle-treated slices, and many Fos-immunoreactive cells were still present in the cerebral cortex. However, by $2 \mathrm{~d}$ in vitro, most slices showed only low levels of Fos-like immunostaining in the striatum and in the cortex, and by $3 \mathrm{~d}$ in vitro Fos-like protein expression was very low, with a few Fos-positive nuclei in the ventrolateral striatum and pallidum and scattered Fos-positive nuclei in the cortex (Fig. 2B).

Based on these findings, slices were cultured for $3 \mathrm{~d}$ in nearly all experiments so as to minimize basal levels of OGS Fos ex-

Figure 2. Basal and stimulated levels of expression of OGS Fos-like protein in the striatum cultured for 4 hr or 3 d. Photomicrographs illustrating OGS Fos-like immunostaining in striatal slices cultivated in vitro for $4 \mathrm{hr}\left(A, A^{\prime}, D, E\right)$ or for $3 \mathrm{~d}\left(B, B^{\prime}, C, D^{\prime}, E^{\prime}\right)$ before being challenged for 3 hr with the nonselective dopamine receptor agonist apomorphine $\left(A^{\prime}, B^{\prime}, C, D, D^{\prime}, E, E^{\prime} ; 10 \mu \mathrm{M}\right)$ or with the vehicle for apomorphine, $0.5 \%$ ethanol in $0.9 \%$ saline $(A, B)$. An entire slice cultured for $3 \mathrm{~d}$ and treated with apomorphine is illustrated in $C$. In the 4 hr vehicle-treated slice culture $(A)$, there is a high level of basal expression of OGS Fos-like immunoreactivity in the striatum, including scattered clusters of weakly stained Fos-positive cells in the lateral striatum (example at asterisk). After $3 \mathrm{~d}$ in vitro $(B)$, very few OGS Fos-positive cells are present. $B^{\prime}$ and $D^{\prime}$, In $3 \mathrm{~d}$ cultures treated with apomorphine, the expression of OGS Fos-like protein in the caudoputamen is primarily focused in clusters of cells (examples at asterisks), which correspond to developing striosomes (see Fig. 5 and text). Many Fos-positive cells also appear in the medial compartment $\left(M C^{\prime}\right)$. In $4 \mathrm{hr}$ slice cultures treated with apomorphine $\left(A^{\prime}, D\right)$, the most pronounced Fos-like immunoreactivity is also in cell clusters (examples at asterisks) and the medial compartment, but many Fos-positive cells appeared in the striatal region outside clusters as well. In the neocortex, the expression of OGS Fos-like immunoreactivity also has a more restricted distribution pattern in the $3 \mathrm{~d}$ slice culture $\left(E^{\prime}\right)$ than that in the $4 \mathrm{hr}$ slice culture $(E)$. The Fos-positive cells are primarily concentrated in the deep part of the neocortex (arrowhead) in the $3 \mathrm{~d}$ slice culture, whereas Fos-positive cells are distributed throughout the neocortex in the $4 \mathrm{hr}$ slice culture, with middle and deep layers of enhanced expression. $A C$, Anterior commissure; $B F$, hasal forebrain; $C C$, corpus callosum; $C T X$, neocortex; $C P$, caudoputamen; $S$, septum. Scale bar shown in $A^{\prime}$ indicates $500 \mu \mathrm{m}$ for $A, A^{\prime}, B, B^{\prime}$, and $C$. Scale bars for $D$ and $D^{\prime}$ (in $D^{\prime}$ ) and for $E$ and $E^{\prime}$ (in $E^{\prime}$ ) indicate $100 \mu \mathrm{m}$. 


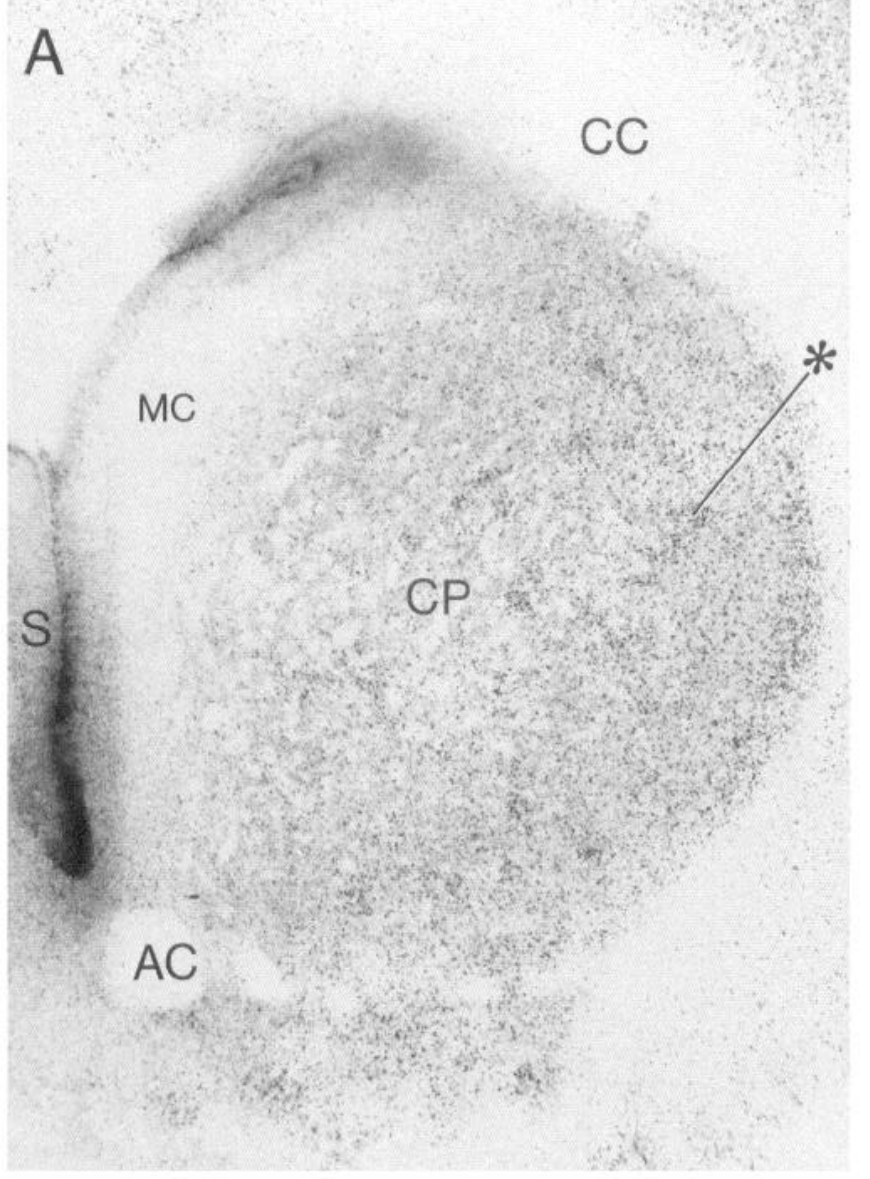

\section{$A^{\prime}$}
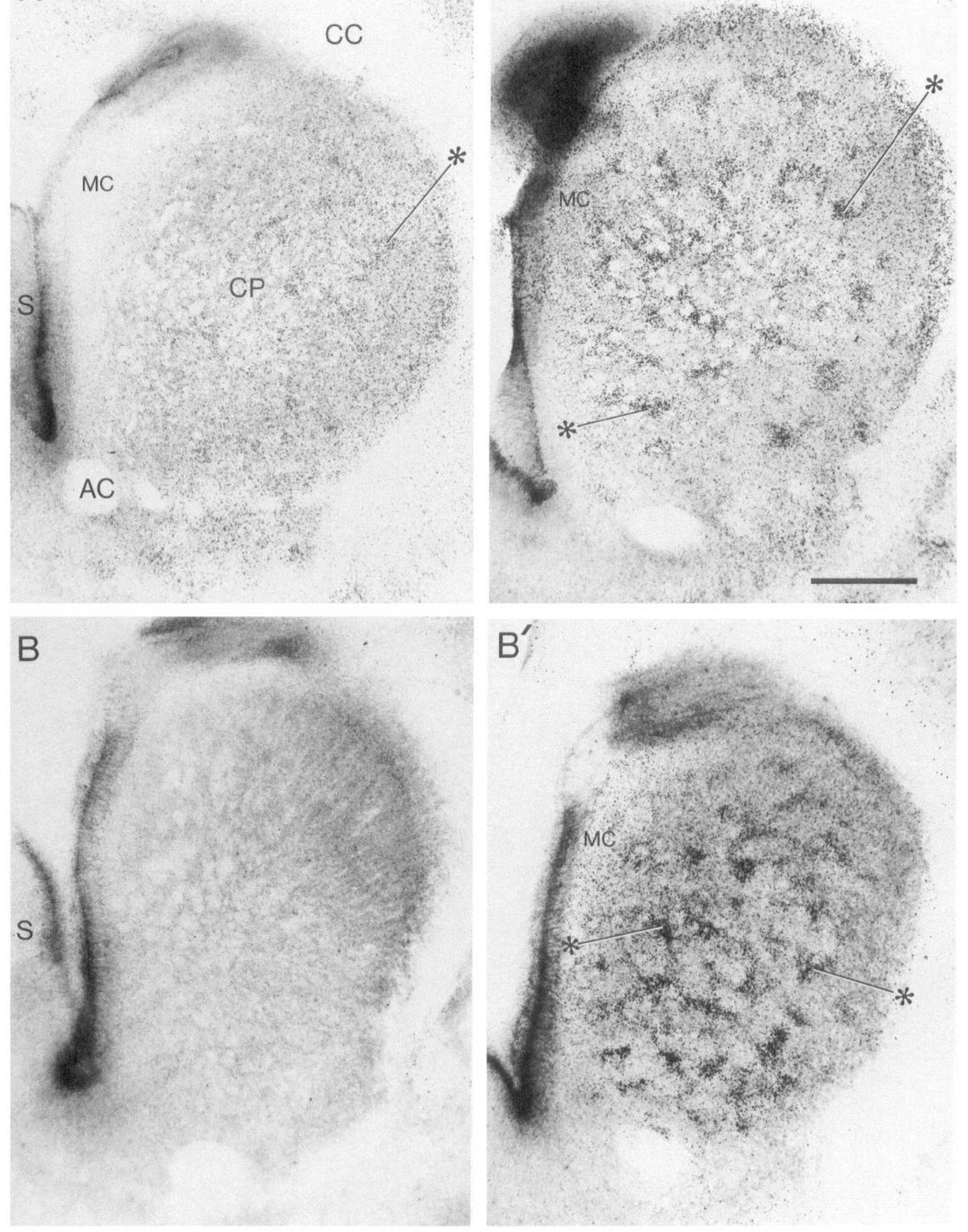

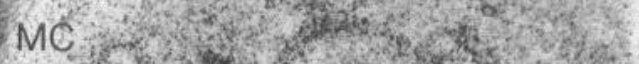
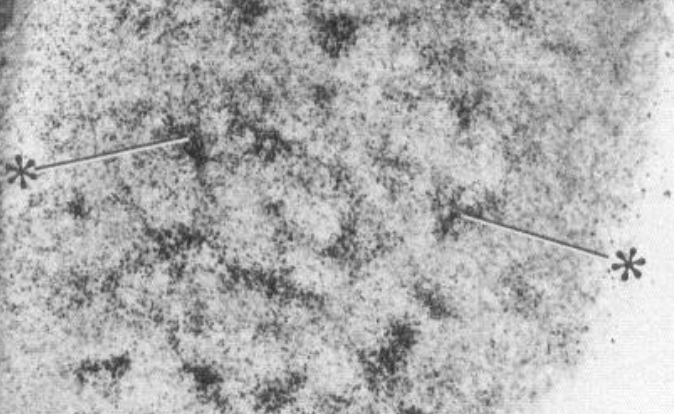

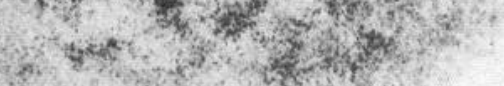



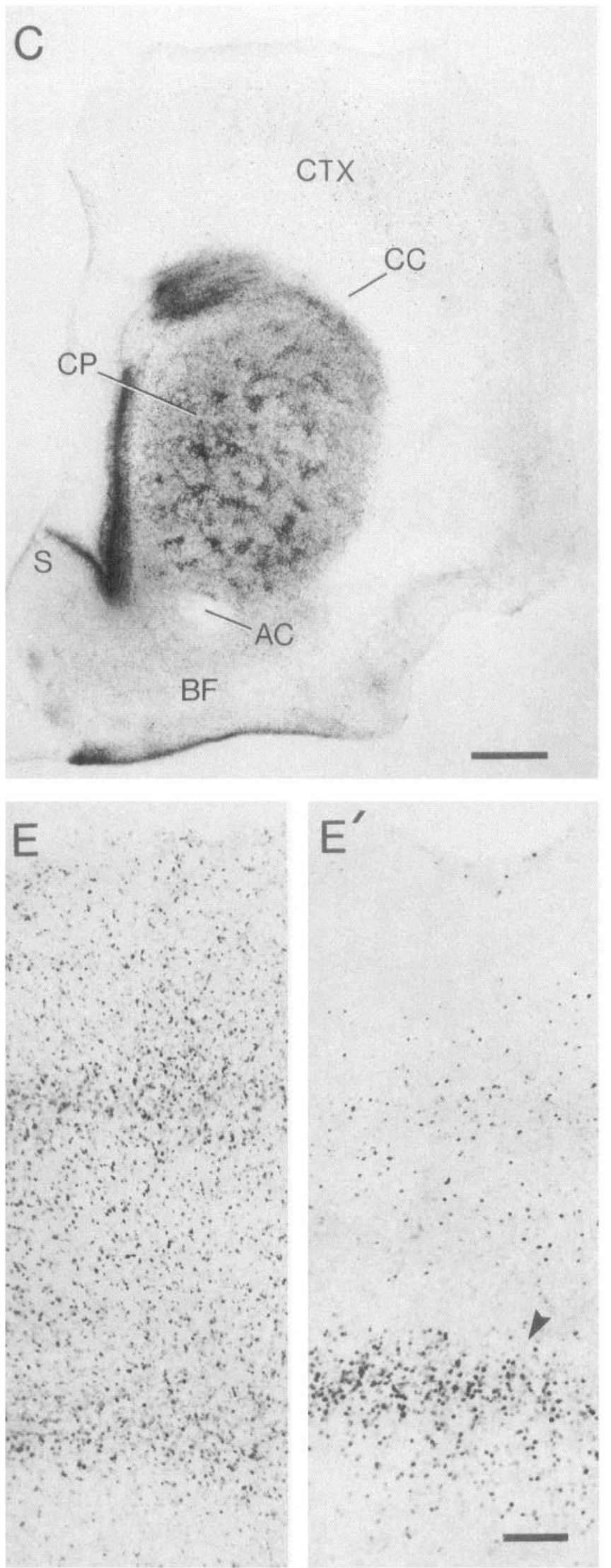
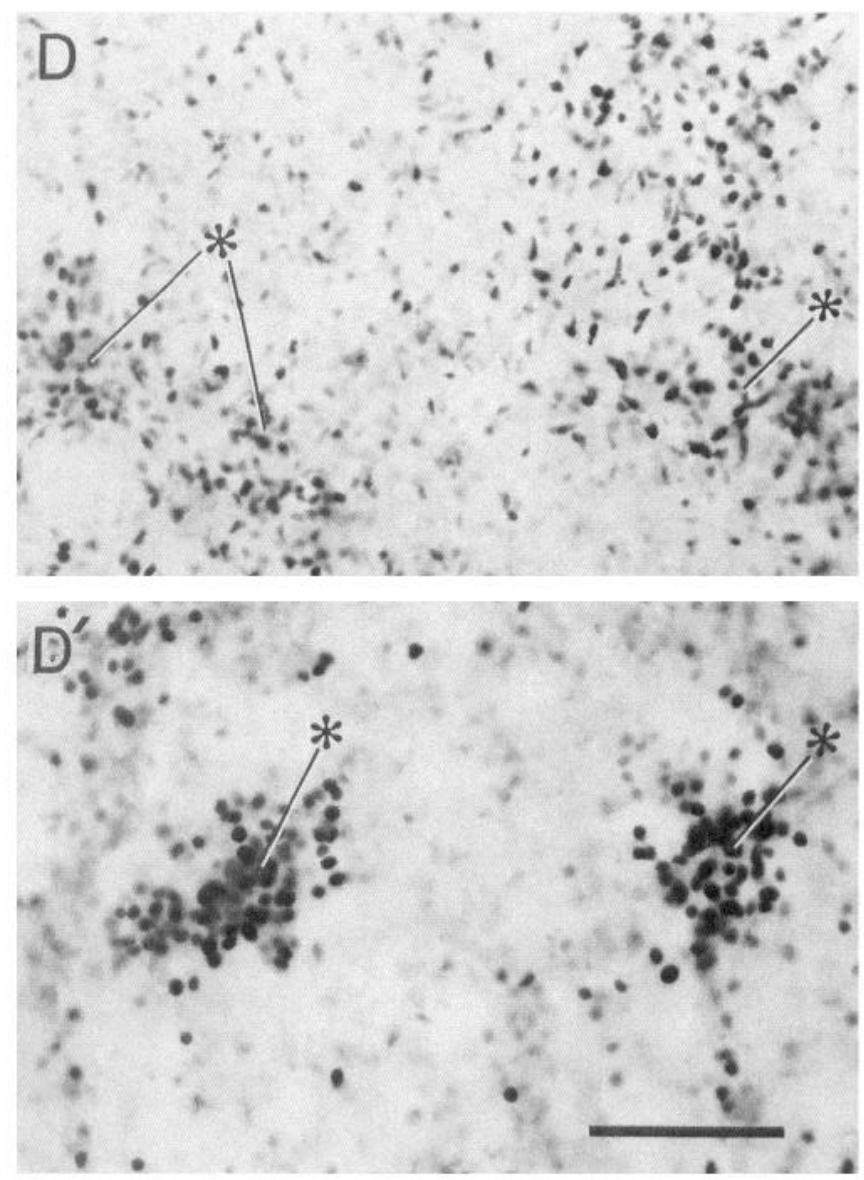


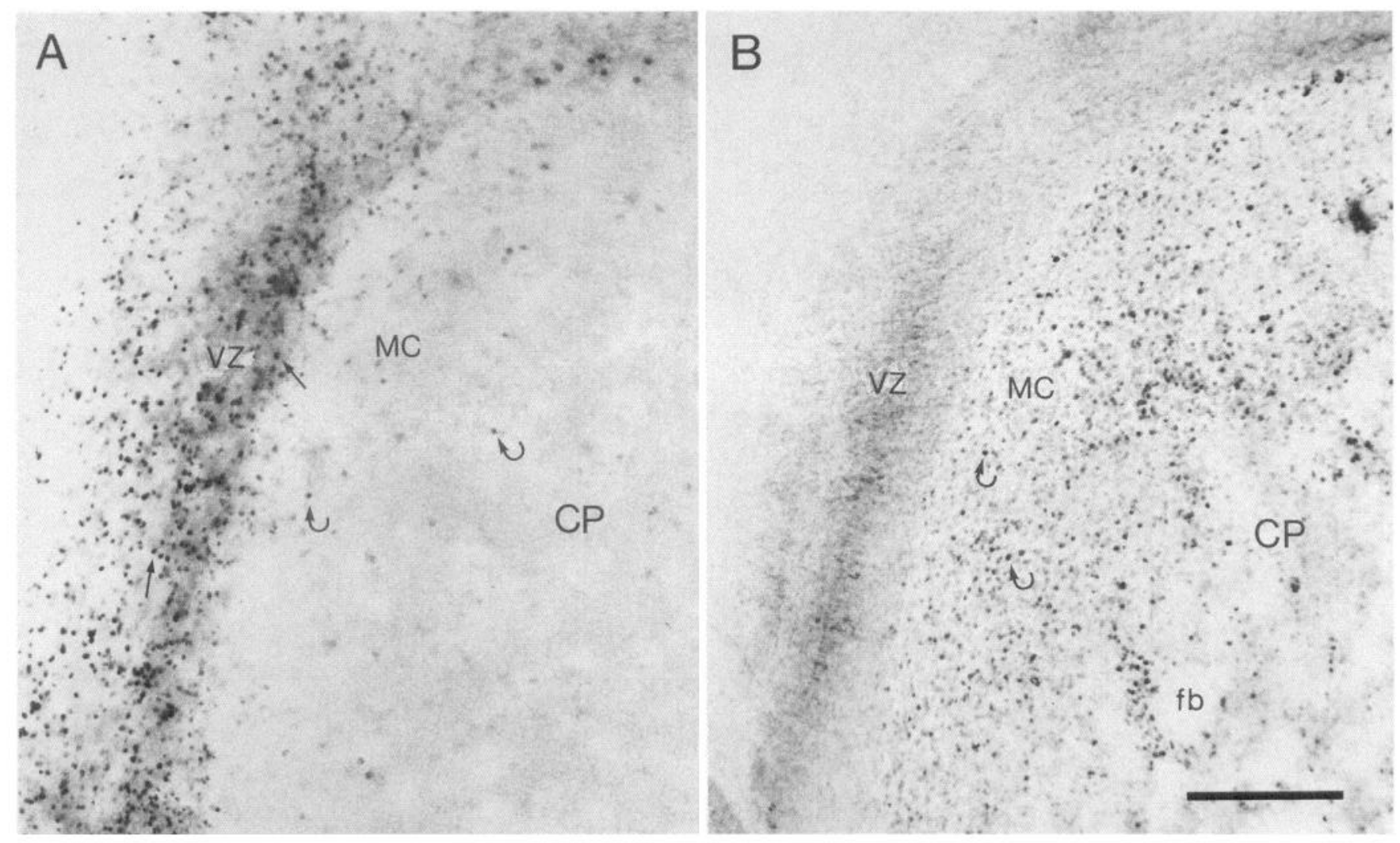

Figure 3. Proliferative ventricular zone and expression of Fos-like protein in the medial compartment. A, Photomicrograph of a $3 \mathrm{~d}$ cultured striatum immunostained for BrdU applied for $3 \mathrm{hr}$ before fixation. Many BrdU-positive cells (examples at arrows) are present in the ventricular zone $(V Z)$. The wide area covered by the distribution of BrdU-positive cells in the ventricular zone is probably due to tissue spreading and flattening outward during cultivation in vitro. A few BrdU-positive cells (examples at curved arrows) are scattered in the medial compartment $(M C)$ and in the striatum proper $(C P)$. B, Photomicrograph of OGS Fos-like immunostaining in a $3 \mathrm{~d}$ cultured striatum challenged with SKF-81297. Many OGS Fos-positive cells (examples at curved arrows) are packed together in the medial compartment adjacent to the ventricular zone, but very few Fospositive cells are present in the ventricular zone. The medial compartment lacks condensed internal capsule fiber bundles $(f b)$. Scale bar for $A$ and $B$ (in $B$ ) indicates $200 \mu \mathrm{m}$.

pression in the tissue before drug application. Except when specified explicitly, the results described below were obtained in such $3 \mathrm{~d}$ cultures. In a small number of slices, regardless of incubation time, diffuse Fos-like immunostaining was present throughout the tissue. The nature of this diffuse Fos-like immunostaining was not clear.

\section{Patterned expression of Fos-like protein in striatal slice cultures exposed to dopamine receptor agonists}

Apomorphine, a dopamine receptor agonist with high affinity for both dopamine D1-like and D2-like receptors ( $1 \mu \mathrm{M}, n=2$; $10 \mu \mathrm{M}, n=5$ ), induced nuclear OGS Fos-like immunoreactivity in $3 \mathrm{~d}$ cultures in highly distinctive anatomical patters both in the striatum (Fig. $2 B^{\prime}, C, D^{\prime}$ ) and in the neocortex (Fig. 2E, $E^{\prime}$ ). Clusters of Fos-positive cells were distributed through the caudoputamen at all but the most rostral levels of the striatum, and many Fos-immunoreactive nuclei were also collected in a band along the dorsolateral edge of the caudoputamen, particularly at caudal levels. In the ventral striatum, Fos-positive cells were sparse except in a focus of immunoreactive cells at the border between the caudal nucleus accumbens and the rostral bed nucleus of the stria terminalis (data not illustrated).

In addition to these regions, there was a prominent medial compartment of the caudoputamen, immediately adjacent to the ventricular zone, in which many Fos-positive nuclei appeared
(Figs. $2 B^{\prime}, 3 B$ ). In this zone, condensed bundles of internal capsule fibers were absent, and there was very little DARPP-32like immunostaining (Fig. $1 A$ ), calbindin- $\mathrm{D}_{28 \mathrm{kD}}-$ like immunostaining (Fig. $1 B$ ) or TH-like immunostaining (Fig. 1C).

Although there was strong basal expression of OGS Fos-like protein in vehicle-treated control slices fixed $4 \mathrm{hr}$ after slicing, we wanted to determine whether the pattern of OGS Fos-like protein induced by dopamine receptor agonists after $3 \mathrm{~d}$ could also be detected as early as a few hours after slicing, when relatively little time for denervation-associated changes had elapsed. As shown in Figure $2, A^{\prime}$ and $D$, clearly patchy OGS Fos-like immunostaining was indeed present in slices stimulated with apomorphine $4 \mathrm{hr}$ after slicing, and the medial compartment in these slices also contained many Fos-positive nuclei.

\section{Dopamine DI-like receptor activation induces Fos-like protein in cultured striatum}

To characterize the dopamine receptor subtypes mediating induction of Fos-like protein, we treated striatal slice cultures with a series of dopamine receptor agonists selective for either D1like or D2-like receptors. Both the full dopamine D1-selective agonist, SKF-81297 (100 nM, $n=5 ; 1 \mu \mathrm{M}, n=1)$ and the partial D1-selective agonist, SKF-38393 $(1 \mu \mathrm{M}, n=3 ; 10 \mu \mathrm{M}$, $n=3$ ) induced pronounced OGS Fos-like immunostaining in clusters of striatal cells and in the medial compartment in pat- 

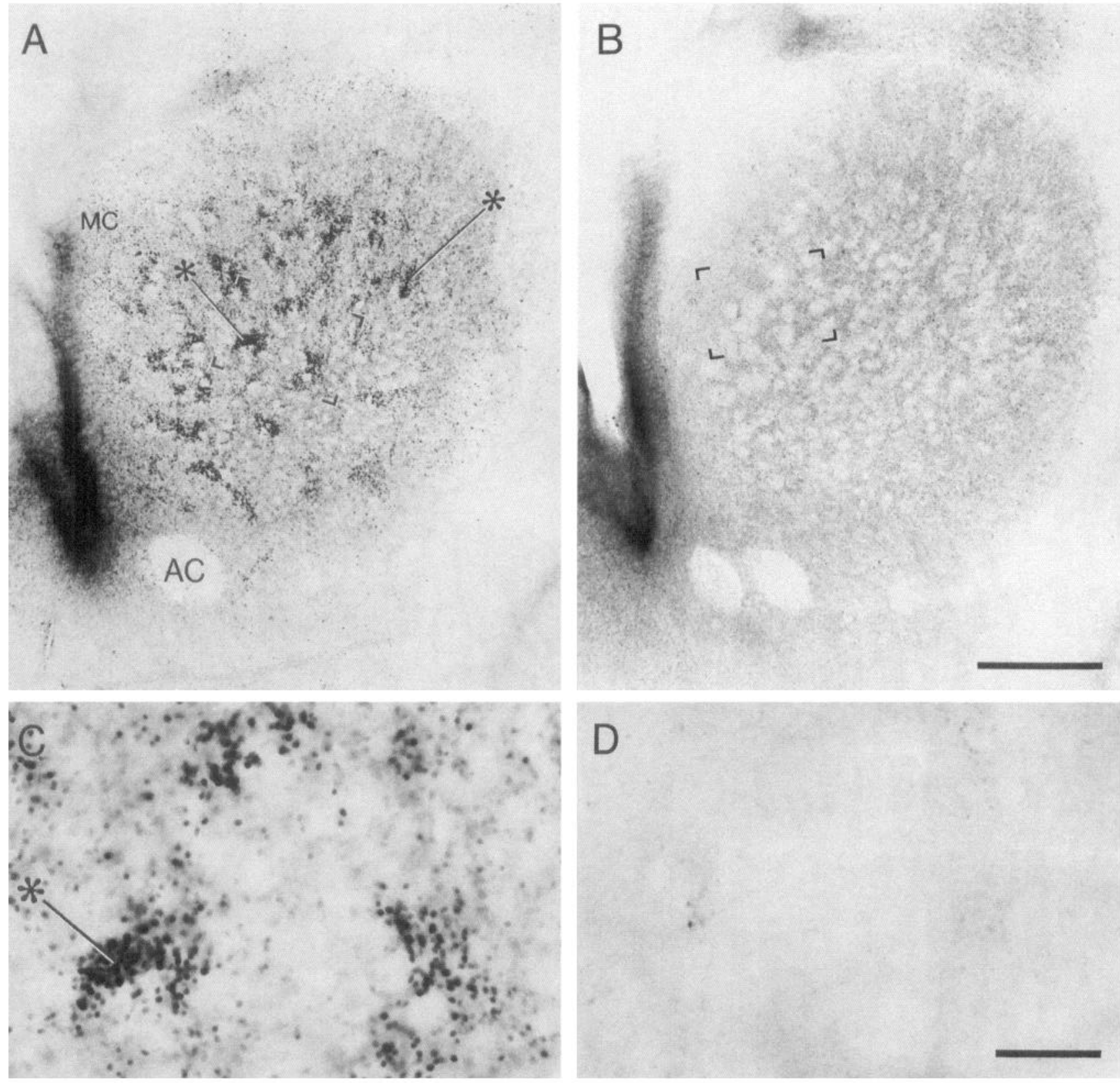

Figure 4. The D1-selective dopamine receptor agonist SKF-81297 activates expression of OGS Fos-like protein primarily in cell clusters in cultured striatum. A, Photomicrograph of distinctly patchy OGS Fos-like immunostaining in a striatal slice cultivated for $3 \mathrm{~d}$ in vitro before treatment with SKF-81297. The bracketed region in $A$ is shown at higher magnification in $C$. The Fos-positive clusters (examples at asterisks) correspond to developing striosomes (see Fig. 5 and text). Fos-positive cells are also present in the medial compartment $(M C)$ ). B, Photomicrograph of OGS Foslike immunostained striatal slice that was cultured for $3 \mathrm{~d}$ in vitro and was then pretreated with SCH-23390, a D1-selective dopamine receptor antagonist, before exposure to SKF-81297. Very little Fos-like immunoreactivity is present. The bracketed region in $B$ is shown at higher magnification in $D$. $A C$, Anterior commissure. Scale bars: $A$ and $B$ (in $B$ ) represents $500 \mu \mathrm{m} ; C$ and $D$ (in $D$ ), $100 \mu \mathrm{m}$.

terns similar to those seen in the slices treated with apomorphine (Fig. $4 A, C$ ). The drugs were effective at concentrations as low as $100 \mathrm{nM}$ for SKF-81297 and $1 \mu \mathrm{M}$ for SKF-38393 and apomorphine (Table 1).

In contrast to the D1-selective agonists, the D2-selective agonist, quinpirole ( $1 \mu \mathrm{M}, n=2 ; 10 \mu \mathrm{M}, n=1)$, did not induce expression of OGS Fos-like immunostaining in more than a few scattered cells either in the striatum or elsewhere (data not shown).

Slices exposed to the full D1-selective agonist SKF-81297
$(100 \mathrm{nM})$ were doubly immunostained for OGS Fos-like protein and for DARPP-32 to determine whether the Fos-rich cell clusters corresponded to clusters of DARPP-32-immunoreactive neurons, which constitute developing striosomes. The evidence for alignment was unequivocal (Fig. 5). Moreover, colocalization of Fos-like immunoreactivity and DARPP-32-like immunoreactivity was observed for many (but not all) individual neurons within the Fos-positive, DARPP-32-positive patches (Fig. 5). However, OGS Fos-positive cells in the medial compartment did not express DARPP-32. Double immunostaining for OGS Fos- 
Table 1. Induction of Fos-like and Fos/Fra-like proteins by dopamine agonists in $3 \mathrm{~d}$ striatal slice cultures and the effects of dopamine receptor antagonists

\begin{tabular}{|c|c|c|c|c|c|c|c|c|c|c|}
\hline \multirow[b]{3}{*}{ Pretreatment } & \multirow{2}{*}{\multicolumn{2}{|c|}{ None }} & \multirow{2}{*}{\multicolumn{2}{|c|}{$\begin{array}{l}\text { Nonselective dopamine } \\
\text { receptor agonist apomorphine }\end{array}$}} & \multicolumn{4}{|c|}{$\underline{\text { Selective D1-like dopamine receptor agonist }}$} & \multirow{2}{*}{\multicolumn{2}{|c|}{$\begin{array}{l}\text { Selective D2-like } \\
\text { dopamine receptor } \\
\text { agonist quinpirole }\end{array}$}} \\
\hline & & & & & \multicolumn{2}{|c|}{ SKF-81297 } & \multicolumn{2}{|c|}{ SKF-38393 } & & \\
\hline & Fos & Fos/Fra & Fos & Fos/Fra & Fos & Fos/Fra & Fos & Fos/Fra & Fos & Fos/Fra \\
\hline SCH-23390 & - & + & - & NA & - & ++ & - & NA & NA & NA \\
\hline Metoclopramide & - & + & $++1+++$ & NA & ++ & +++ & ++ & NA & NA & NA \\
\hline
\end{tabular}

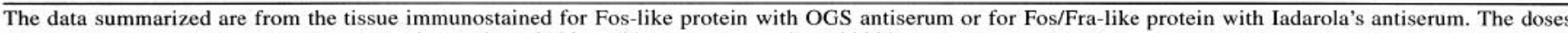

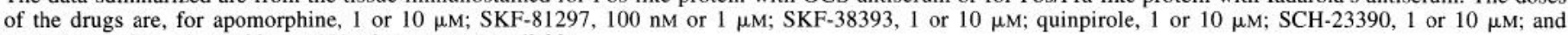
metoclopramide, 10 or $100 \mu \mathrm{M}$. NA, data are not available.

like and PCNA-like proteins indicated that most of the Fospositive cells in the medial compartment were located outside the PCNA-positive ventricular zone proper (data not shown). At most there were only a few scattered Fos-positive cells (and Fos/ Fra-positive cells, see below) present in the ventricular zone of striatal slices treated with dopamine agonists.

\section{Effects of dopamine receptor antagonists on the induction of Fos-like protein in striatal slice cultures suggest selectivity for Dl-like receptors}

Pretreatments with dopamine receptor antagonists confirmed the selectivity of the dopamine receptor agonist effects for D1-like receptors. The D1-selective antagonist, $\mathrm{SCH}-23390(1 \mu \mathrm{M})$, fully or almost completely blocked subsequent induction of OGS Foslike protein expression by administration of either SKF-81297 $(n=2$, Fig. $4 B, D)$, SKF-38393 $(n=3)$ or apomorphine $(n=$ 6 ) both in the striatum proper and in the medial compartment adjoining the ventricular zone (Fig. 4). By contrast, pretreatment with the D2-selective antagonist, metoclopramide (10 and 100 $\mu \mathrm{M})$, did not reduce the activation of striatal OGS Fos-like protein by SKF-81297 (100 nM, $n=5)$, SKF-38393 ( $1 \mu \mathrm{M}, n=$ $2)$, or apomorphine $(10 \mu \mathrm{M}, n=5)$. Preincubation with metoclopramide tended to enhance OGS Fos-like immunostaining in the striatum in some slices treated with apomorphine $(10 \mu \mathrm{M}$; data not shown), but no such effect was seen with the D1-selective agonists. Neither SCH-23390 $(n=2)$, nor metoclopramide $(n=4)$, nor their vehicle, saline $(n=4)$, given by themselves, induced expression of Fos-like protein in the striatum above background levels.

\section{Induction of Fos-like protein in cultured striatum by forskolin and by cAMP analogs}

Dopamine D1-like receptors are known to be coupled positively to adenylate cyclase, the activation of which leads to an increase in the second messenger, cAMP (Kebabian and Calne, 1979; Sibley et al., 1993), and both of the dopamine D1-selective agonists we used, SKF-81297 and SKF-38393, have been shown to stimulate adenylate cyclase in the striatum (Nielsen et al.,
Figure 5. OGS Fos-positive cells correspond to DARPP-32-positive striosomal neurons identified by double labeling. Confocal images illustrating the same field in caudoputamen of a $3 \mathrm{~d}$ slice culture treated with SKF-81297 for $3 \mathrm{hr}$ and processed with double immunofluorescent markers for OGS Foslike immunoreactivity and DARPP-32like immunoreactivity. A cluster of Fos-positive $(A)$ and DARPP-32-positive $(B)$ cells is shown. Many neurons in the striosomal cell clusters coexpress Fos-like immunoreactivity and DARPP32-like immunoreactivity (examples at arrows). A few DARPP-32-positive cells are not double labeled (examples at arrowheads). Scale bar for $A$ and $B$ (in $A$ ) indicates $20 \mu \mathrm{m}$.
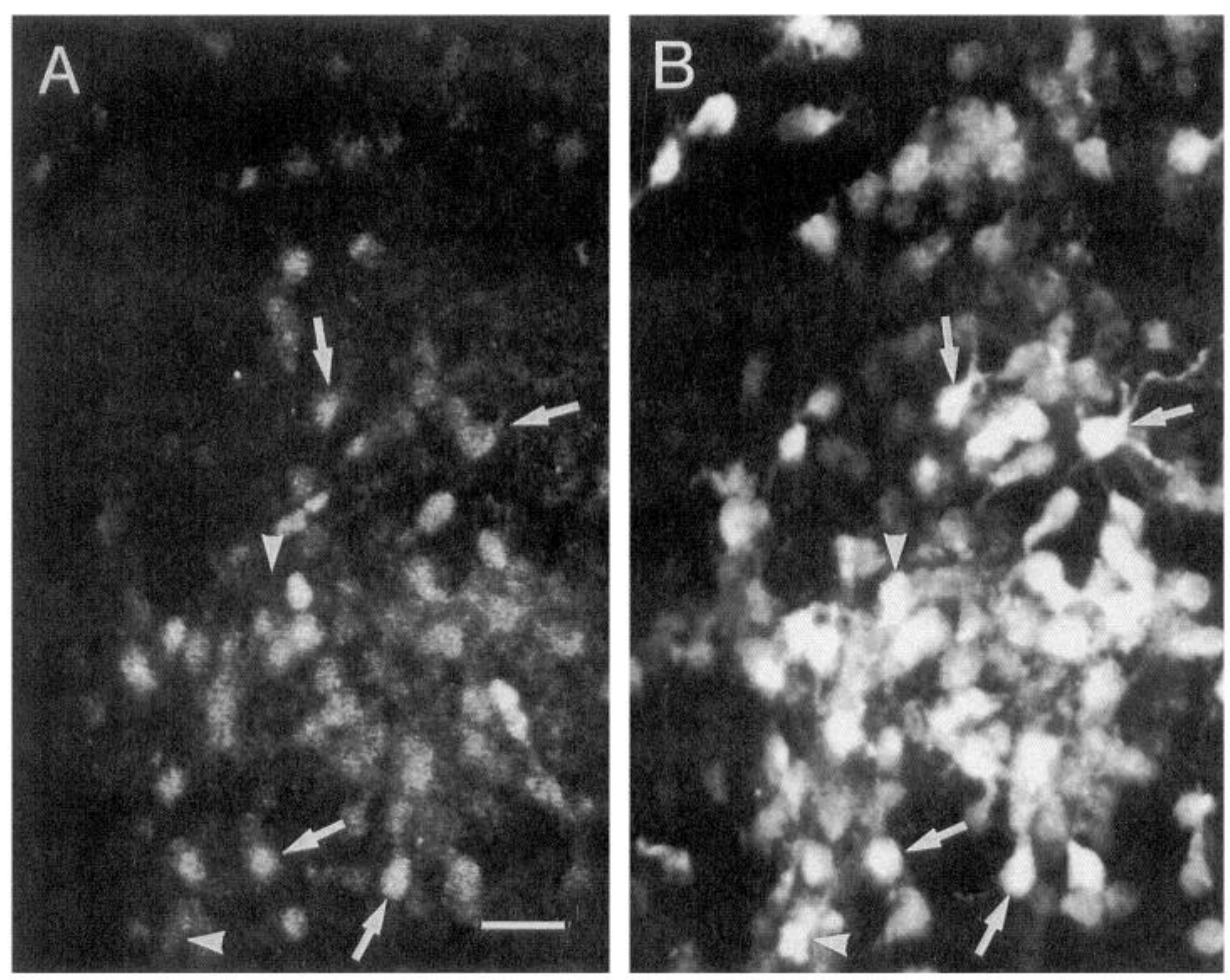

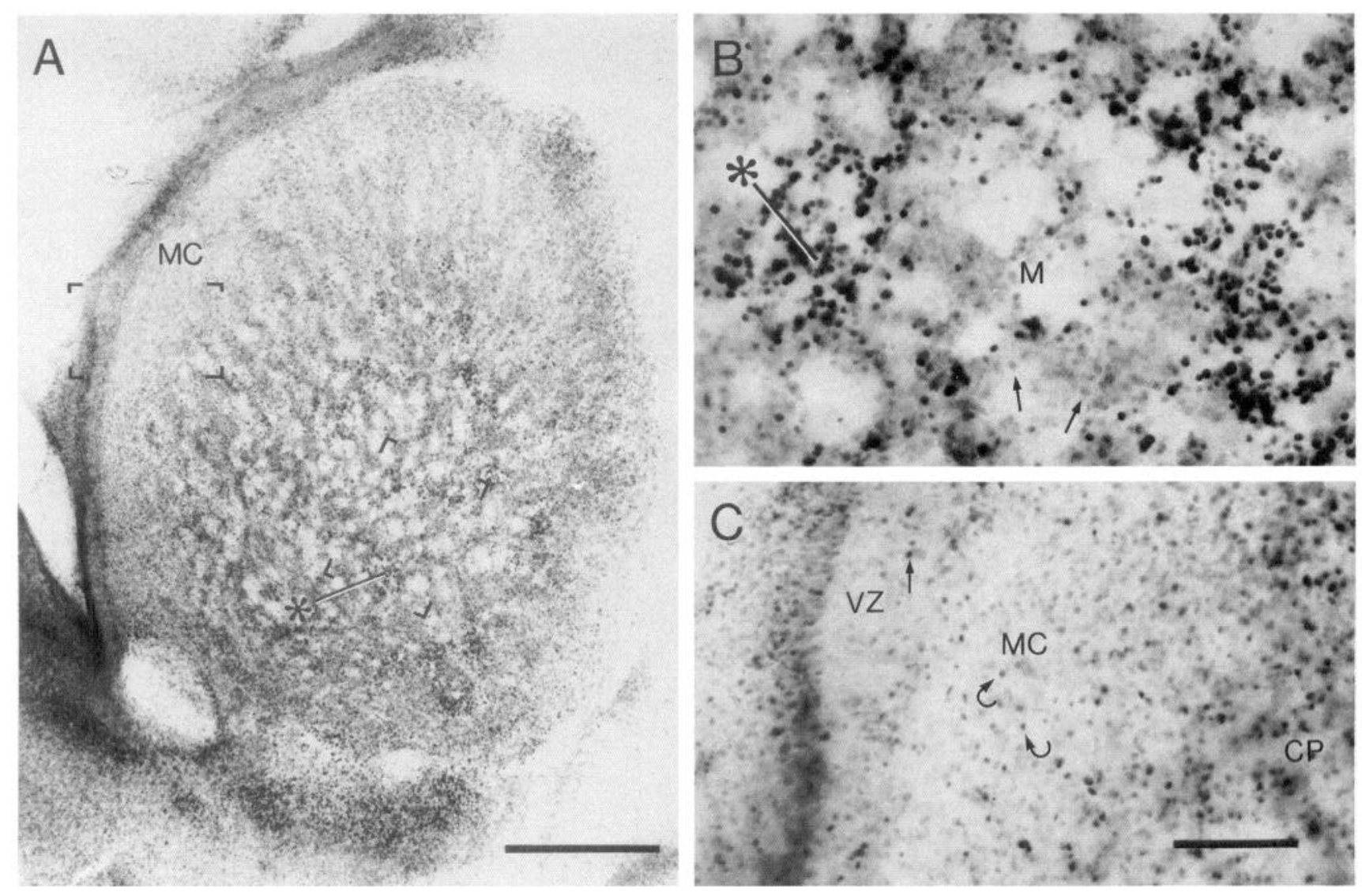

Figure 6. Forskolin induces expression of OGS Fos-like protein both in striosomes and in matrix of striatal slice cultures. A, Photomicrograph of OGS Fos-like immunostaining in a striatal slice cultured for $3 \mathrm{~d}$ in vitro and then treated with forskolin ( $10 \mu \mathrm{M}, 3 \mathrm{hr})$. Fos-like immunoreactivity is detectable both in striosomes (example at asterisk) and in the surrounding matrix. $B$ and $C$ illustrate at higher magnification the regions bracketed in $A$ in the striatum proper and in the medial compartment $(M C)$. The immunostaining of Fos-positive neurons (examples at arrows in $B$ ) in the matrix $(M)$ is weaker than that of neurons in developing striosomes ( $B$, example at asterisk), as is that of Fos-positive cells (examples at curved arrows in $C$ ) in the medial compartment. A few Fos-positive cells (example at arrow in $C$ ) appear in the ventricular zone (VZ). $C P, C a u d o p u t a m e n$. Scale bar in $A$ indicates $500 \mu \mathrm{m}$; scale bar for $B$ and $C$ (in $C$ ) indicates $100 \mu \mathrm{m}$.

1989; Andersen and Jansen, 1990). We therefore stimulated a series of slices with forskolin ( $10 \mu \mathrm{M}, n=5)$ to determine whether direct activation of adenylate cyclase would, as expected, lead to expression of Fos-like immunoreactivity, and whether, if so, the distribution of Fos-positive striatal neurons would be similar to that seen following D1 agonist treatment.

Forskolin induced robust expression of nuclear Fos-like protein in clusters of striatal neurons corresponded to developing striosomes (Fig. 6A), and many individual neurons in the clusters were doubly immunostained for Fos-like and DARPP-32-like proteins (data not shown). However, in contrast to slices treated with dopamine receptor agonists, those treated with forskolin showed marked induction of OGS Fos-like immunostaining in the matrix as well (Fig. 6A,B). Striosomes still appeared differentially immunostained, because for any given neuron in the matrix, the forskolin-induced Fos immunostaining was weaker than that in nearby striosomal neurons (Fig. 6B). Nevertheless, many neurons in the matrix were Fos-positive. Moreover, although forskolin and D1 agonist treatments were similar in inducing Fos-like protein in many cells in the medial compartment, forskolin also induced Fos-like protein in cells of the ventricular zone in some of the slices (Fig. $6 C$ ).

The specificity of these immunostaining patterns was tested by treating control slices with the vehicle for forskolin (dimethyl sulfoxide, $n=2)$ and with 1,9-dideoxy-forskolin $(n=2)$, a forskolin-like molecule that does not stimulate adenylate cyclase. These treatments did not induce expression of Fos-like protein in more than a few cells in the striatum (data not shown).

To further test the involvement of cAMP in inducing expression of Fos-like protein in the striatal slices, slices were treated with the cAMP analogs, dibutyryl-cAMP ( 1 and $3 \mathrm{mM}, n=1$ for each dose) and Sp-cAMPS (100 $\mu \mathrm{M}, 1 \mathrm{mM}, n=1$ for each dose) (O'Brian et al., 1982). These cAMP analogs increased expression of Fos-like protein in the cultured striatum homogeneously in a dose-dependent manner. Dibutyryl-cAMP at 3 $\mathrm{mM}$ induced nuclear Fos-like immunostaining in more striatal cells than did either $1 \mathrm{~mm}$ dibutyryl-cAMP or $1 \mathrm{~mm}$ Sp-cAMPS (data not shown). Sp-cAMPS at $100 \mu \mathrm{M}$ was not effective in inducing expression of Fos-like protein.

\section{Expression of Fos-like protein in cultured striatum in response to phorbol ester treatments}

To test whether activation of $\mathrm{Ca}^{2+} /$ phospholipid-dependent protein kinase (protein kinase $\mathrm{C}$ ) would stimulate the expression of Fos-like protein in the developing striatum, we applied phorbol ester (PMA) to cultured slices in two sets of experiments. In the first, we administrated submicromolar or low micromolar doses (40.5, 81, 162, 486, and $810 \mathrm{nM}, n=1$ or 2 for each dose, and 
$1.62 \mu \mathrm{M}, n=2$ ). Even at the highest submicromolar doses, PMA either did not induce or induced little OGS Fos-like immunostaining in the striatum. PMA at the dose of $1.62 \mu \mathrm{M}(n=2)$ induced Fos-like protein in some scattered cells in the cultured striatum. In a second set of experiments, with higher doses of PMA (16.2 and $96.6 \mu \mathrm{M}, n=2$ for each dose), strong activation of Fos-like protein occurred. The immunostaining present in the striatum showed a decreasing medial to lateral gradient and Foslike protein was also expressed in the medial compartment (data not shown). The control of PMA, $4 \alpha$-PMA, which does not activate protein kinase $\mathrm{C}$, did not induce Fos-like protein expression in the cultured striatum at 1.62 , or $16.2 \mu \mathrm{M}(n=1$ for each dose). However, $4 \alpha-$ PMA at $96.6 \mu \mathrm{M}(n=2)$ induced weak Fos-like protein expression in some cell clusters and in the lateral streak of the striatum in some of the slices.

\section{Different constitutive and stimulus-induced patterns of expression of Fos-like and Fos/Fra-like proteins in the cultured striatum}

When slices were treated with SKF-81297 and were then pro cessed with OGS anti-Fos antiserum that had been preabsorbed with the OGS peptide immunogen, no staining appeared. Staining was also nil when the primary antiserum was omitted from the incubation solution. These controls suggested that the OGS Fos-like immunostaining was selective for the peptide sequence, SGFNADYEASSSRC (corresponding to amino acid sequence 4-17 of human fos), which was used to raise the OGS antiserum.

This selectivity does not, however, constitute proof that Fos, as opposed to one or more Fos-related antigens (Fras), was the protein detected in our experiments. In an additional set of experiments, we therefore applied apomorphine $(n=2)$, SKF$81297(n=3)$, dibutyryl-cAMP $(n=2)$, forskolin $(n=3)$, quinpirole $(n=2)$, or their vehicles, (apomorphine vehicle, $n=$ 1; SKF-81297 vehicle, $n=2$; forskolin vehicle, $n=2$; quinpirole vehicle, $n=2$ ), and stained the slices with a polyclonal anti-Fos/Fra antiserum raised against the conserved amino acid sequence 128-152 of Fos and Fra proteins (Young et al., 1991). We employ the terms, "Fos/Fra" and "Fos/Fra-like" proteins only to refer to the Fos/Fra-like antigens recognized by this antiFos/Fra antiserum. Young et al. (1991), Zhang et al. (1992), Dilts et al. (1993), and Bronstein et al. (1994) have presented evidence that this polyclonal antiserum recognizes Fos-like and Fra-like proteins that are induced in vivo by both apomorphine and by the indirect dopamine receptor agonist, cocaine. We also pretreated slices with SCH-23390 (1 $\mathrm{MM}, n=2)$ or with metoclopramide (10 and $100 \mu \mathrm{M}, n=1$ for each dose) before SKF81297 exposure, and exposed other slices to $\mathrm{SCH}-23390$ alone ( $1 \mu \mathrm{M}, n=2$ ) or to metoclopramide alone (10 and $100 \mu \mathrm{M}, n$ $=1$ for each dose).

Both the constitutive and the induced patterns of Fos/Fra-like immunostaining in the striatum were different from those seen with the OGS Fos antiserum (Fig. 7). In contrast to the very low constitutive expression of Fos-like protein in vehicle-treated $3 \mathrm{~d}$ striatal slice cultures, there was a strong basal expression of Fos/ Fra-like protein in the striatum. The most prominent immunostaining appeared in clusters of striatal cells which were distributed either broadly or, in a few slices, primarily medially (Fig. $7 A$ ) in a surround of weaker staining. Constitutive expression of Fos/Fra-like protein also occurred in the medial compartment in aggregates of cells and in scattered cells as well. The constitutive expression of Fos/Fra-like protein in the cultured striatum was not blocked either by the D1-selective antagonist SCH-23390 (1 $\mu \mathrm{M}, n=2$ ) or by the D2-selective antagonist metoclopramide ( 10 and $100 \mu \mathrm{M}, n=1$ for each dose).

Apomorphine and SKF-81297, but not quinpirole, induced prominent expression of Fos/Fra-like protein throughout the cultured caudoputamen. Induction in striosomes was more extensive than in the unstimulated slices, and there was also considerable enhancement of Fos/Fra-like immunostaining in the matrix (Fig. $7 B, D$ ). Such marked agonist-induced expression in the matrix was not found for OGS Fos-like protein following the same treatments (Fig. 4C). The expression of Fos/Fra-like protein in the striatal medial compartment was also greatly enhanced relative to that of OGS Fos (Fig. $7 B$ ). There was also pronounced Fos/Fra-like immunostaining in the ventral striatum-nucleus accumbens regions in the agonist-treated cultures, in contrast to the low levels of OGS Fos-like immunostaining found there following treatment with the same agonists (Fig. $7 B$ ).

Only partial blockade of Fos/Fra-like protein expression could be documented in SKF-81297-treated slices pretreated with SCH 23390 and compared with SKF-81297 controls. The blockade of induction had to be judged against constitutive levels of Fos/Fra-like protein expression, which were themselves insensitive to SCH-23390. In each of two experiments, a decrease in the medial compartment was obvious; a decrease in the matrix was evident in one of these, but for striosomes, it was unclear whether a decrease occurred in either experiment.

Metoclopramide pretreatment had no detectable effect on SKF-81297 induction of Fos/Fra-like protein, as found also for OGS Fos. Forskolin, which induced OGS Fos-like protein in the matrix at much lower levels than in striosomes, increased the expression of Fos/Fra-like protein almost equally strongly in striosomes and matrix. Striosomes had only slightly higher intensity of Fos/Fra-like immunostaining than did adjacent regions of the matrix. Forskolin strongly enhanced Fos/Fra-like protein expression in the medial compartment, but not in the ventricular zone. Patterns of Fos/Fra-like immunostaining similar to those observed after forskolin treatment were also evident in slices treated with the cAMP analog, dibutyryl-cAMP (1 and $3 \mathrm{mM}$ ), with higher doses inducing higher levels of expression (data not shown).

Effects of cycloheximide on the induction of Fos-like and Fos/ Fra-like proteins in striatal slice cultures

To test whether the observed Fos-like and Fos/Fra-like immunoreactivity induced by SKF-81297 was derived from de novo synthesis of protein, $3 \mathrm{~d}$ cultured striatal slices were preincubated with the protein synthesis inhibitor, cycloheximide. Cycloheximide (10 $\mu \mathrm{M}, n=2 ; 50 \mu \mathrm{M}, n=2)$ strongly inhibited expression of Fos-like and Fos/Fra-like proteins induced by SKF-81297 in the cultured slices. Interestingly, incubation of slices with cycloheximide alone did not cause a significant decrease of constitutive expression of Fos/Fra-like protein in the cultured striatum (data not shown).

Effects of protein kinase inhibitors on dopaminergic induction of Fos-like protein in striatal slice cultures

In an attempt to identify intracellular kinase pathways that might mediate the Fos response to stimulation of D1-like receptors, striatal slices were maintained in vitro for $3 \mathrm{~d}$ and were then stimulated with SKF-81297 in the presence of different protein kinase inhibitors. The effects of these reagents on forskolin-induced Fos-like protein expression was also tested. The results 

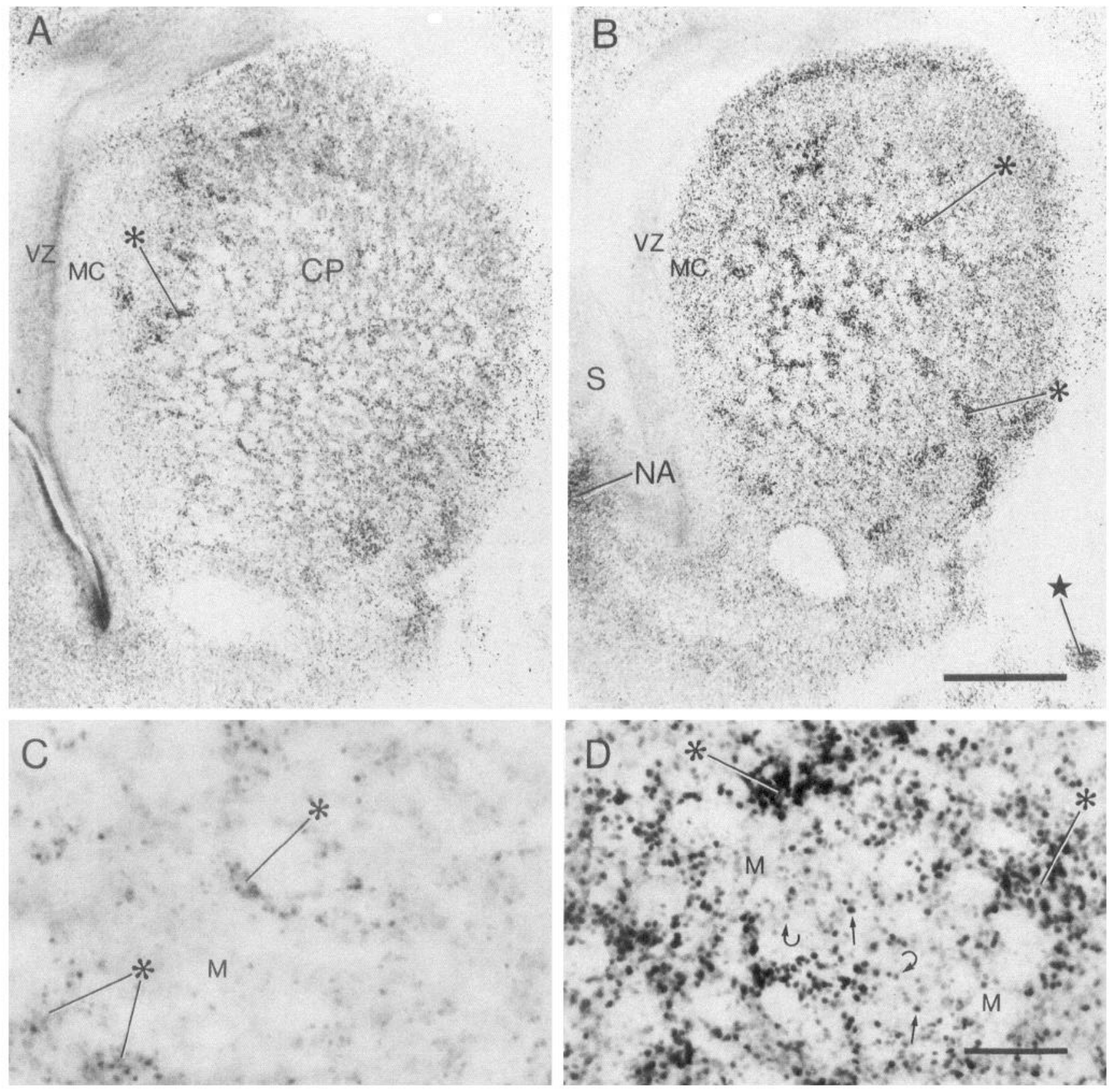

Figure 7. Basal and stimulated levels of Fos/Fra-like protein expression in the striatum cultured for $3 \mathrm{~d}$ in vitro. Photomicrographs of Fos/Fralike immunostaining detected in $3 \mathrm{~d}$ slice cultures treated with the D1-selective dopamine receptor agonist SKF-81297 $(B, D)$ or with the vehicle for SKF-81297 $(A, C) . A$ and $C$, There are high basal levels of Fos/Fra-like immunoreactivity in the vehicle-treated slice culture, in contrast to OGS Fos-like immunoreactivity (see Fig. $2 B$ ). The Fos/Fra-positive nuclei are enriched in striosomal cell clusters, especially medially (examples at asterisks) and are scattered through the medial compartment $(M C)$, but are rare in the ventricular zone $(V Z)$. $B$ and $D$, In the SKF-81297-treated slice, many Fos/Fra-positive cells are present in the extrastriosomal matrix $(M)$, and expression in the striosomes (examples at asterisks) is very intense. Some of the Fos/Fra-positive cells in the matrix are strongly stained (examples at arrows in $D$ ) whereas others are weakly stained (examples at curved arrows in $D$ ). Many Fos/Fra-positive cells are also present in the medial compartment. Note that strong Fos/Fra-like immunoreactivity is induced in the nucleus accumbens (NA) and in the islands of Calleja (star). Scale bar for $A$ and $B$ (shown in $B$ ) indicates $500 \mu \mathrm{m}$; scale bar for $C$ and $D$ (shown in $D$ ) indicates $100 \mu \mathrm{m}$. $S$, Septum.

are summarized in Table 2. For the inhibitors with marked effects on Fos-like protein expression, inhibition of general protein synthesis was also tested. As a final control, we tested whether any of the kinase inhibitors by themselves induced Fos-like protein expression in the cultured striatum. None did.

Preincubation of slices with $\mathrm{H} 7(50,100 \mu \mathrm{M})$ or $\mathrm{H} 8(100 \mu \mathrm{M})$, both of which are general inhibitors of cyclic nucleotide-dependent protein kinases and protein kinase $\mathrm{C}$ at the doses indicated, abolished or almost completely abolished striatal OGS Fos-like protein expression induced by SKF-81297 or forskolin. A lower dose of $\mathrm{H} 8(50 \mu \mathrm{M})$ partially blocked the expression of OGS Fos-like protein in some slices and did not block in others. 
Table 2. Effects of protein kinase inhibitors on expression of Fos-like protein in $3 \mathrm{~d}$ cultured striatum

\begin{tabular}{lll} 
& Agonists & \\
\cline { 2 - 3 } Kinase inhibitors & SKF-81297 (100 nM) & Forskolin $(10 \mu \mathrm{M})$ \\
\hline Rp-cAMPS $(1 \mathrm{mM})$ & ++ & ++ \\
H7 $(50,100 \mu \mathrm{M})$ & - & - \\
H8 $(50 \mu \mathrm{M})$ & + & + \\
H8 $(100 \mu \mathrm{M})$ & - & - \\
H89 $(30,60,90,120,300 \mu \mathrm{M})$ & ++ & ++ \\
H89 $(600 \mu \mathrm{M})$ & + & + \\
H85 $(30 \mu \mathrm{M})$ & ++ & ++ \\
H85 $(600 \mu \mathrm{M})$ & ++ & ++ \\
W7 $(100 \mu \mathrm{M})$ & ++ & $\mathrm{NA}$ \\
KN62 $(30 \mu \mathrm{M})$ & ++ & ++ \\
H89 $(30 \mu \mathrm{M})$ and W7 $(100 \mu \mathrm{M})$ & ++ & ++ \\
H89 $(30 \mu \mathrm{M})$ and KN62 $(30 \mu \mathrm{M})$ & ++ & ++ \\
H89 $(300 \mu \mathrm{M})$ and KN62 $(30 \mu \mathrm{M})$ & ++ & ++ \\
H8 $(50 \mu \mathrm{M})$ and W7 $(100 \mu \mathrm{M})$ & ++ & ++ \\
H8 $(50 \mu \mathrm{M})$ and KN62 $(30 \mu \mathrm{M})$ & ++ & +
\end{tabular}

Data show the effects of pretreatments with protein kinase inhibitors on OGS Fos-like immunostaining in the striatum of cultured slices treated with SKF-81297 or forskolin. The intensity and pattern of immunostaining were rated according to the following scale: ++ , normal pattern of immunostaining similar to that induced by the agonists alone; + , partially reduced immunostaining; -, complete or almost complete blockade of immunostaining. Each experiment was performed at least in duplicate. NA, data are not available.

To test the possibility that the inhibition of Fos-like protein induction by $\mathrm{H} 7$ and $\mathrm{H} 8$ might be due to nonspecific inhibitory effects of the kinase inhibitors, the status of protein synthesis in the presence of the kinase inhibitors was assessed by measuring ${ }^{35} \mathrm{~S}$-methionine incorporation in the cultured slices. Pretreatments.with the blocking $50 \mu \mathrm{M}$ dose of $\mathrm{H} 7$ resulted in a ca. $13 \%$ decrease in ${ }^{35} \mathrm{~S}$-methionine incorporation, whereas pretreatments with the blocking dose of $\mathrm{H} 8(100 \mu \mathrm{M})$ resulted in a ca. $36 \%$ decrease. The nearly total blockade of induction of Fos-like protein by $\mathrm{H} 7$, especially, thus seems unlikely to be due to the partial reduction of protein synthesis found with this inhibitor.

Unexpectedly, pretreatments with the H89 kinase inhibitor at a dose within the range of concentrations selective for protein kinase A (30 $\mu \mathrm{M}$; Chijiwa et al., 1990) did not affect the expression of Fos-like protein induced by SKF-81297 or forskolin. The concentration of $\mathrm{H} 89$ had to be increased to $600 \mu \mathrm{M}$ before partial blockade occurred, and even at this dose, which is beyond the dose-range selective for protein kinase $A$, there was only partial (estimated $30-50 \%$ ) reduction in OGS Fos-like protein expression. At this extreme dose, the $\mathrm{H} 89$ preincubation led to a ca. $76 \%$ reduction of ${ }^{35} \mathrm{~S}$-methionine incorporation, indicating a significant decrease in general protein synthesis. The massive inhibition of protein synthesis indicated that the inhibitor likely could penetrate the tissue of the slices, suggesting that the failure of blockade of Fos-like protein expression by $\mathrm{H} 89$ did not simply reflect lack of penetration of the inhibitor into the slice tissue. H85, a control inhibitor for $\mathrm{H} 89$ that is far less selective than $\mathrm{H} 89$ for protein kinase A at the dose of $30 \mu \mathrm{M}$, did not affect or only slightly reduced the expression of OGS Fos-like protein at doses as high as $600 \mu \mathrm{M}$.

Pretreating striatal slices with a second protein kinase $A$ inhibitor, the membrane-permeable Rp-cAMPS ( $1 \mathrm{mM}$; O'Brian et al., 1982), also did not significantly inhibit striatal OGS Fos-like protein induction by SKF-81297 or forskolin. Rp-cAMPS (1 $\mathrm{mM}$ ) did, however, partially antagonize OGS Fos-like protein expression induced by Sp-cAMPS (1 mM) in the cultured striatum.

Finally, pretreating striatal slices with $\mathrm{KN} 62$ at $30 \mu \mathrm{M}$, an inhibitor of calcium/calmodulin dependent protein kinase II (CaM kinase II), did not reduce the induction of Fos-like protein by SKF-81297, nor did the calmodulin inhibitor, W7 at $100 \mu \mathrm{M}$. Instead, in a few slices, each of these pretreatments appeared to enhance the OGS Fos-like immunostaining induced by SKF81297.

The lack of blockade by single protein kinase inhibitors could reflect the presence of multiple kinase pathways capable of activating Fos-like protein. In PC12 cells, for example, $c$-fos induction has been reported to occur through phosphorylation of cAMP response element-binding protein (CREB) by both protein kinase A and CaM kinase II (Sheng et al., 1990, 1991; Dash et al., 1991; Bading et al., 1993). We therefore concurrently applied different pairs of kinase inhibitors to determine whether it was still possible to induce expression of Fos-like protein by SKF-81297 or forskolin. Pretreating slices with H89 (30 $\mu \mathrm{M}$ or $300 \mu \mathrm{M})$ and KN62 $(30 \mu \mathrm{M})$, with H89 $(30 \mu \mathrm{M})$ and W7 (100 $\mu \mathrm{M})$, with $\mathrm{H} 8(50 \mu \mathrm{M})$ and $\mathrm{KN} 62(30 \mu \mathrm{M})$, or with H8 $(50 \mu \mathrm{M})$ and W7 $(100 \mu \mathrm{M})$ did not significantly inhibit the expression of OGS Fos-like protein in the striatum of slices stimulated either with SKF-81297 or forskolin.

\section{Discussion}

The experiments we report here establish the organotypic slice culture as a valuable system for studying the regulation of gene expression in the developing striatum. Under the culture conditions we used, cell survival in the striatum was high up to at least $3 \mathrm{~d}$ in vitro, the germinal zone was mitotically active, striosome-matrix compartmentation was maintained, striatal neurons expressed striatum-enriched antigens in typical patterns, and they were able to generate dopamine D1-like receptor-mediated and cAMP-dependent responses to extracellular stimulation by 
activating expression of Fos-like and Fra-like gene products. These responses were striatal compartment-specific and differed for different gene products of the fos-jun family. We suggest that there are individually distinct maturational programs for activation of even closely related genes coupled to developing dopamine receptor-mediated signal transduction pathways in the striatum. The unusual pharmacologic profile of the responses to protein kinase inhibitors raises the further possibility that novel protein kinase A-like molecules may participate in the transduction from membrane to nucleus of the striatal neurons.

Advantages of organotypic cultures of striatum over dissociated cell cultures and cell lines as an in vitro approach

By tending to preserve much of the physiologically relevant environment of developing striatal neurons, the organotypic striatal slice culture represents a system more anatomically and physiologically relevant than cultures of cell lines (Cattaneo and McKay, 1990; Evrard et al., 1990) or dissociated primary striatal cells (Panula et al., 1979; Bockaert al., 1986). The maintenance of the infrastructure for cell-cell interactions in slice cultures allows the development and cell biology of striatal neurons to be analyzed in an approximately in situ condition. These special properties, and the experimentally accessible condition of cells in the slices, make the organotypic culture of striatum a valuable compromise paradigm between in vivo whole animal and in vitro dissociated cell culture approaches.

Activation of dopamine DI-like receptors in vitro induces selective expression of Fos-like and Fos/Fra-like proteins in neurons of developing striosomes and matrix

The activation of OGS Fos-like protein by D1-like receptor agonists was highly concentrated in the developing striosomes. This selectivity is consistent with evidence that developing striosomes are enriched in D1-like receptor binding sites relative to the surrounding matrix (Murrin and Zeng, 1989; Caboche et al., 1991; Liu and Graybiel, unpublished observations), although the distribution of D1 receptor mRNA with respect to compartmentation in developing striatum remains to be clarified (Guennoun and Bloch, 1992; Schambra et al., 1994). The failure of dopamine D1-like receptor agonists to stimulate the expression of high levels of Fos-like protein in matrix neurons was not, however, due to a poor survival capacity of this population of cells, nor to a lack of functional D1-like dopamine receptors in the matrix. Many developing calbindin- $\mathrm{D}_{28 \mathrm{kD}}-$ positive and MAP-2positive neurons were present in the matrix of the cultured striatum, and D1-selective agonists did activate widespread expression of Fos/Fra-like protein in the matrix. Notably, strong induction of Fos-like protein was observed in slices cultured for as short a time as $4 \mathrm{hr}$, so that denervation supersensitivity had a relatively short time to occur. The D1-selective effects we saw were thus not simply the result of prolonged effects of culturing.

These findings suggest that the developmental heterogeneity in the response capacity of striosome and matrix neurons involves not simply maturation of dopamine receptor subtypes functionally coupled to corresponding second messengers, but also differential targeting of fos-jun family gene products by the intracellular messenger cascades activated in the two compartments. These differences in gene regulation may presage some of the striking differences in neurochemistry and connectivity of these striatal compartments at adulthood.

Fos/Fra-like protein, but not Fos-like protein, was constitutively expressed in the $3 \mathrm{~d}$ striatal cultures. This fits with findings for the normal developing rat striatum in vivo (Alcantara and Greenough, 1993; Fusco et al., 1994). Our findings in vitro suggest that the constitutive expression of Fos/Fra-like protein in the developing striatum is not dependent on intact innervation by extrinsic afferents, is not sensitive to D1-like receptor blockade, and is not dependent on recent ongoing protein synthesis.

Involvement of $c A M P$, adenylate cyclase, and protein kinase $C$ in the induction of Fos-like protein in cultured striatum

The evidence that cAMP analogs and forskolin induced strong expression of OGS Fos-like immunoreactivity in neurons of striosomes and some induction in matrix neurons supports the view that cAMP was involved in the dopamine receptor-mediated activation of Fos-like protein in the striatal slice cultures. This evidence is in accord with the well-known positive coupling of D1-like receptors to adenylate cyclase (Sibley et al., 1993), and the fact that CAMP can lead to activation of Fos protein in PCl2 cells (Sassone-Cori et al., 1988; Fisch et al., 1989). Induction of $c$-fos and Fos-like protein by forskolin has also been observed in cultures of dissociated striatal cells $(\mathrm{He}$ and Hong, 1991) and in the adult striatum in vivo (Simpson and McGinty, 1994).

Stimulation of D1-like receptors has been shown to activate protein kinase C in striatal cell cultures (McMillian et al., 1992), and activated protein kinase $\mathrm{C}$ can induce $c$-fos in transfected cell lines (Fisch et al., 1987; Gilman, 1988). We were unable to demonstrate convincingly that activation of protein kinase $C$ with PMA induced expression of Fos-like protein in the cultured striatum. Intense Fos immunostaining was present only with high doses of PMA. We cannot exclude the possibility that, at such dose levels, PMA had nonspecific effects.

\section{Effects of protein kinase inhibitors on expression of Fos-like protein in cultured striatum}

The results of our kinase inhibition experiments, taken together with the induction of Fos-like protein by cAMP analogs and adenylate cyclase activators, clearly favor the view that protein kinase A is involved in the induction of Fos-like protein by D1 agonists in the neonatal striatum. However, H89, a selective inhibitor of protein kinase A in PC12 cells at low doses, did not block OGS Fos induction unless it was applied at cytotoxic levels, and then it only blocked partially. Nor did the protein kinase A inhibitor Rp-cAMPS.

At least three alternatives might account for these results. First, despite our control experiments, we cannot discount the possibility that the lack of blockade by $\mathrm{H} 89$ resulted from inadequate penetration of the slices. This seems an unlikely explanation for the lack of inhibition by Rp-cAMPS, however, which is membrane permeable. Second, it is possible that there are redundant kinase pathways capable of inducing Fos or Fras in the slices, even in the presence of the paired kinase inhibitors we tested. In particular, protein kinase $\mathrm{C}$ may be involved, as the kinase inhibitors $\mathrm{H} 7$ and $\mathrm{H} 8$ which were effective in blocking induction also inhibit protein kinase $\mathrm{C}$ at the doses tested. It seems unlikely, however, that protein kinase $\mathrm{A}$ would not be involved, and thus the failure of the selective protein kinase A inhibitors to block induction remains a puzzle.

An intriguing alternative possibility raised by our findings is that the developing striatum may express a novel isoform of protein kinase A capable of mediating the gene activation we observed. Several lines of evidence already suggest that signal transduction in the striatum may involve novel molecules dif- 
ferentially enriched in the striatum. These include the $G$ protein, $G_{\text {oll }}$ (Drinnan et al., 1991; Hervé et al., 1993), the striatum-enriched adenylate cyclase, $\mathrm{AC}_{\text {ST }}$ (Glatt and Snyder, 1993), the cAMP-regulated phosphoprotcins, ARPP-16, ARPP-21, and ARPP-90 (Ouimet et al., 1989; Walaas et al., 1989; Girault et al., 1990), the calmodulin-dependent phosphodiesterase 1B1 (63 kDa) (Bentley et al., 1992; Polli and Kincaid, 1992, 1994; Yan et al., 1994), the striatum-enriched tyrosine phosphatase, STEP (Lombroso et al., 1991, 1993), and the protein phosphatase-1 inhibitor, DARPP-32 (Ouimet et al., 1984). The presence of these molecules, and especially of those related to cAMP function, make the possibility of a novel kinase $\mathrm{A}$ an attractive alternative to pursue.

\section{A medial compartment of the developing striatum}

Fos-like and Fos/Fra-like proteins were induced by dopamine receptor agonists, by forskolin, and by high concentrations of PMA in a medial compartment of the cultured striatum immediately adjacent to the ventricular zone. We show that this zone is not, in contrast to the ventricular zone, mitotically active in the slice cultures, as though it were not a subventricular zone but part of the striatum proper. However, it does not express appreciable levels of DARPP-32, calbindin- $\mathrm{D}_{2 \times \mathrm{kD}}$, or $\mathrm{TH}$, nor contain mature GFAP-positive astrocytes, all characteristics of the adjacent striatum. These findings raise the possibility that the Fos-and Fos/Fra-positive cells in the medial compartment are postmitotic cells poised to migrate into the striatum proper but not yet activated to express their full striatal phenotypes. Interestingly, study of the developing cat striatum indicates that this zone may represent a "waiting compartment" in which previously pulse-labeled ${ }^{3} \mathrm{H}$-thymidine-positive cells pile up prior to migration (Newman-Gage, Liu, and Graybiel, unpublished observations). It also appears to correspond to a medial zone which has specialized pseudocholinesterase staining properties in the fetal striatum of both human and cat brains (Graybiel and Ragsdale, 1980; Ragsdale and Graybiel, 1983). Although this medial compartment does not show high levels of D1-like receptor binding (Murrin and Zeng, 1989; Caboche et al., 1991; Liu and Graybiel, unpublished observations) or D1 dopamine receptor mRNA (Guennoun and Bloch, 1992), the functional assay we used may have detected D1-like receptors expressed at low levels in this population of cells. This suggests that striatal cells at the beginning of migration may already express functional dopamine receptors coupled to expression of Fos-like and Fra-like proteins.

\section{Regulation of striatal genes by dopamine}

Dopamine receptor agonists regulate the expression of neuropeptides, neurotransmitters, receptors and associated molecules in the striatum (Graybiel, 1990, 1993b; Gerfen, 1992a,b; Nestler, 1992). For example, stimulating D1-like receptors and blocking D2-like receptors differentially increase and decrease, respectively, prodynorphin mRNA and proenkephalin mRNA in the striatum (Hong et al., 1978; Hanson et al., 1987; Li et al., 1988; Sivam, 1989; Gerfen et al., 1990; Hurd et al., 1992; Daunais et al., 1993; Hurd and Herkenham, 1993; Jian et al., 1993; Steiner and Gerfen, 1993; Bronstein et al., 1994). The physiological effects of such regulation may influence multiple levels of neuronal plasticity in relation to striatal input-output processing, both during development and at maturity. As several of the regulated molecules such as prodynorphin and proenkephalin have been shown to have sequences resembling the consensus AP-1 sequence in their promoters, by means of which they could bind Fos/Jun family dimers, the suggestion has been made that their regulation may involve transcription factors of this family (e.g., Sonnenberg et al., 1989; Graybiel et al., 1990; Naranjo et al., 1991; Graybiel, 1993b; Hyman et al., 1993; Bronstein et al., 1994). An advantage of the striatal slice culture preparation we report here is that some of these questions can now be addressed in vitro. Such work could have a major impact on understanding the cell and molecular biology underlying development and neuroplasticity in the striatum.

\section{References}

Alcantara AA, Greenough WT (1993) Developmental regulation of Fos and Fos-related antigens in cerebral cortex, striatum, hippocampus, and cerebellum of the rat. J Comp Neurol 334:75-85.

Anderson PH, Jansen JA (1990) Dopamine receptor agonists: selectivity and dopamine D1 receptor efficacy. Eur J Pharmacol Mol Pharmacol Sect 188:335-347

Bading H, Ginty DD, Greenberg ME (1993) Regulation of gene expression in hippocampal neurons by distinct calcium signaling pathways. Science 260:181-186.

Batchelor PE, Armstrong DM, Blaker SN, Gage FH (1989) Nerve growth factor receptor and choline acetyltransferase colocalization in meurons within the rat forebrain: response to fimbria-fornix transection. J Comp Neurol 284:187-204.

Bentley JK, Kadlecek A, Sherbert CH, Seger D, Sonnenburg WK, Charbonneau H, Novack JP, Beavo JA (1992) Molecular cloning of cDNA encoding a " 63 "-kDa calmodulin-stimulated phosphodiesterase from bovine brain. J Biol Chem 267:18676-18682.

Berretta S, Robertson HA, Graybiel AM (1992) Dopamine and glutamate agonists stimulate neuron-specific transcriptional activation of c-fos in the striatum. J Neurophysiol 68:767-777.

Bockaert J, Gabrion J, Sladeczek F, Pin J-P, Recasens M, Sebben M, Kemp D, Dumuis A (1986) Primary culture of striatal neurons a model of choice for pharmacological and biochemical studies of neurotransmitter receptors. J Physiol (Paris) 81:219-227.

Brewer GJ, Cotman CW (1989) Survival and growth of hippocampal neurons in defined medium at low density: advantages of a sandwich culture technique or low oxygen. Brain Res 494:65-74.

Bronstein DM, Ye H, Pennypacker KR, Hudson PM, Hong J-S (1994) Role of a $35 \mathrm{kDa}$ fos-related antigen (FRA) in the long-term induction of striatal dynorphin expression in the 6-hydroxydopamine lesioned rat. Mol Brain Res 23:191-203.

Caboche J, Rogard M, Besson MJ (1991) Comparative development of D1-dopamine and mu opiate receptors in normal and in 6-hydroxydopamine-lesioned neonatal rat striatum: dopaminergic fibers regulate mu but not D1 receptor distribution. Dev Brain Res 58:111-122.

Cattaneo E, McKay RDG (1990) Nerve growth factor regulates proliferation and differentiation of ncuronal stem cells. Nature 347:762765.

Chijiwa T, Mishima A, Hagiwara M, Sano M, Hayashi K, Inoue T, Naito K, Toshioka T, Hidaka H (1990) Inhibition of forskolin-induced neurite outgrowth and protein phosphorylation by a newly synthesized selective inhibitor of cyclic AMP-dependent protein kinase, $N$-[2-( $p$ bromocinnamylamino)ethyl]-5-isoquinolinesulfonamide (H-89), of PC12D pheochromocytoma cells. J Biol Chem 265:5267-5272.

Cole AJ, Bhat RV, Patt C. Worley PF, Baraban JM (1992) D, dopamine receptor activation of multiple transcription factor genes in rat striatum. J Neurochem 58:1420-1426.

Dash PK, Karl KA, Colicos MA, Prywes R, Kandel ER (1991) cAMP response element-binding protein is activated by $\mathrm{Ca}^{2+} / \mathrm{calmodulin}-$ as well as cAMP-dependent protein kinase. Proc Natl Acad Sci USA 88:5061-5065.

Daunais JB, Roberts DCS, McGinty JF (1993) Cocaine self-administration increases preprodynorphin, but not $c$-fos mRNA in rat striatum. Neuroreport 4:543-546.

Dilts RP, Helton TE, McGinty JF (1993) Selective induction of Fos and Fra immunoreactivity within the mesolimbic and mesostriatal dopamine terminal fields. Synapse 13:251-263.

Drinnan SL, Hope BT, Snutch TP, Vincent SR (1991) $\mathrm{G}_{\text {olf }}$ in the basal ganglia. Mol Cell Neurosci 2:66-70.

Evrard C, Borde I, Marin P, Galiana E, Permont J, Gros F, Rouget P 
(1990) Immortalization of bipotential and plastic glio-neuronal precursor cells. Proc Natl Acad Sci USA 87:3062 3066.

Fisch TM, Prywes R, Roeder RG (1987) c-fos sequences necessary for basal expression and induction by epidermal growth factor, 12-Otetrasecanoyl phorbol-13-acetate, and the calcium ionophore. Mol Cell Biol 7:3490-3502.

Fisch TM, Prywes R, Simon MC, Roeder RG (1989) Multiple sequence elements in the c-fos promotor mediate induction by cAMP. Genes Dev 3:198-211.

Foster GA, Schultzberg M, Hökfelt T, Goldstein M, Hemmings HC Jr, Ouimet CC, Walaas SI, Greengard P (1987) Development of a dopamine- and cyclic adenosine $3^{\prime}: 5^{\prime}$-monophosphate-regulated phosphoprotein (DARPP-32) in the prenatal rat central nervous system, and its relationship to the arrival of presumptive dopaminergic innervation. J Neurosci 7:1994-2018.

Fusco E, Milbrandt JD, Iadarola MJ, Graybicl AM (1994) Prenatal delineation of the striosomal system by selective transcription factor expression. Soc Neurosci Abstr 20:1697.

Garner CC, Brugg B, Matus A (1988) A 70-kilodalton microtubuleassociated protein (MAP2c), related to MAP2. J Neurochem 50:609615.

Gerfen CR (1992a) The neostriatal mosaic: multiple levels of compartmental organization. Trends Neurosci 15:133-139.

Gerfen CR (1992b) $D_{1}$ and $D_{2}$ dopamine receptor regulation of striatonigral and striatopallidal neurons. Semin Neurosci 4:109-118.

Gerfen CR, Baimbridge KG, Miller JJ (1985) The neostriatal mosaic: compartmental distribution of calcium-binding protein and parvalbumin in the basal ganglia of the rat and monkey. Proc Natl Acad Sci USA 82:8780-8784.

Gerfen CR, Engber TM, Mahan LC, Susel Z, Chase TN, Monsma FJ Jr, Sibley DR (1990) D1 and D2 dopamine receptor-regulated gene expression of striatonigral and striatopallidal neurons. Science 250: I $429-1432$.

Gilman MZ (1988) The c-fos serum response element responds to protein kinase C-dependent and -independent signals but not to cyclic AMP. Genes Dev 2:394-402.

Girault J-A, Horiuchi A, Gustafson EL, Rosen NL, Greengard P (1990) Differential expression of ARPP-16 and ARPP-19, two highly related cAMP-regulated phosphoproteins, one of which is specifically associated with dopamine-innervated brain regions. J Neurosci 10:11241133

Glatt CE, Snyder SH (1993) Cloning and expression of an adenyly] cyclase localized to the corpus striatum. Nature 361:536-538.

Graybiel AM (1984) Correspondence between the dopamine islands and striosomes of the mammalian striatum. Neuroscience 13:11571187.

Graybiel AM (1990) Neurotransmitters and neuromodulators in the basal ganglia. Trends Neurosci 13:244-254.

Graybiel AM (1993a) Functions of the nigrostriatal system. Clin Neurosci $1: 12-17$.

Graybiel AM (1993b) Acute effects of psychomotor stimulant drugs on gene expression in the striatum. In: National Institute on Drug Abuse research monograph series, Vol 125, Activation of immediate early genes by drugs of abuse (Grzanna R, Brown RM, eds), pp 7281. Rockville, MD: U.S. Department of Health and Human Services.

Graybiel AM, Ragsdale CW (1980) Clumping of acetylcholinesterase activity in the developing striatum of the human fetus and young infant. Proc Natl Acad Sci USA 77:1214-1218.

Graybiel AM, Moratalla R, Robertson HA (1990) Amphetamine and cocaine induce drug-specific activation of the c-fos gene in striosomematrix and limbic subdivisions of the striatum. Proc Natl Acad Sci USA 87:6912-6916.

Grzanna R, Brown RM, eds (1993) National Institute on Drug Abuse research monograph series, Vol 125 , Activation of immediate early genes by drugs of abuse. Rockville, MD: U.S. Department of Health and Human Scrvices.

Guennoun R, Bloch B (1992) Ontogeny of D1 and DARPP-32 gene expression in the rat striatum: an in situ hybridization study. Mol Brain Res 12:131-139.

Hanson GR, Merchant KM, Letter AA, Bush L, Gibb JW (1987) Methamphetamine-induced changes in the striatal-nigral dynorphin system: role of D-1 and D-2 receptors. Eur J Pharmacol 144:245-246.

He XP, Hong JS (1991) Dopamine receptor agonists induced the expression of dynorphin and c-Fos in primary cell cultures of rat. Soc Neurosci Abstr 17:381.
Hervé D, Lévi-Strauss M, Marey-Semper I, Verney C, Tassin J-P, Glowinski $J$, Girault $J-\Lambda$ (1993) $G_{\text {olf }}$ and $G_{s}$ in rat basal ganglia: possible involvement of $G_{\text {olf }}$ in the coupling of dopamine $D_{1}$ receptor with adenylyl cyclase. J Neurosci 13:2237-2248.

Hockfield S, McKay RDG (1985) Identification of major cell classes in the developing mammalian nervous system. J Neurosci 5:33103328.

Hong JS, Yang H-YT, Fratta W, Costa E (1978) Rat striatal methionineenkephalin content after chronic treatment with cataleptogenic and noncataleptogenic antischizophrenic drugs. J Pharmacol Exp Ther 205:141-147.

Hsu SM, Raine L, Fanger H (1981) Use of avidin-biotin-peroxidase complex $(\mathrm{ABC})$ in immunoperoxidase techniques - a comparison between $\mathrm{ABC}$ and unlabeled antibody (PAP) procedures. $J$ Histochem Cytochem 29:577-580.

Hurd YL, Hcrkenham M (1993) Molecular alterations in the neostriatum of human cocaine addicts. Synapse 13:357-369.

Hurd YL, Brown EE, Finlay JM, Fibiger HC, Gerfen CR (1992) Cocaine administration differentially alters mRNA expression of striatal peptides. Mol Brain Res 13:165-170.

Hyman SE, Kosofsky BE, Nguyen TV, Cohen BM, Comb MJ (1993) Everything activates $c$-fos - how can it matter? In: National Institute on Drug Abuse research monograph series, Vol 125, Activation of immediate early genes by drugs of abuse (Grzanna R, Brown RM, eds), pp 25-38. Rockville, MD: U.S. Department of Health and Human Services.

Hyttel J (1983) SCH 23390 the first selective dopamine D-1 antagonist. Eur J Pharmacol 91:153.

Jian M, Staines WA, Iadarola MJ, Roberston GS (1993) Destruction of the nigrostriatal pathway increases Fos-like immunoreactivity predominantly in striatopallidal neurons. Mol Brain Res 19:156-160.

Kebabian JW, Calne DB (1979) Multiple receptors for dopamine. Nature 277:93-96.

Klymkowsky MW (1988) Metabolic inhibitors and intermediate filament organization in human fibroblasts. Exp Cell Res 174:282-290.

LaHoste GJ, Jen Y, Marshall JF (1993) Striatal Fos expression is indicative of dopamine D1/D2 synergism and receptor supersensitivity. Proc Natl Acad Sci USA 90:7451-7455.

Lankford KL, DeMello FG, Klein WL (1988) $D_{1}$-type dopamine receptors inhibit growth cone motility in cultured retina neurons: evidence that neurotransmitters act as morphogenic growth regulators in the developing central nervous system. Proc Natl Acad Sci USA 85: 2839-2843.

Lendahl U, Zimmermann LB, McKay RDG (1990) CNS stem cells express a new class of intermediate filament protein. Cell 60:585595.

Li S., Sivam SP, McGinty JF, Jiang H-K, Douglass J, Calavetta L, Hong JS (1988) Regulation of the metabolism of striatal dynorphin by the dopaminergic system. J Pharmacol Exp Ther 246:403-408.

Liu F-C, Graybiel AM (1992a) Heterogeneous development of calbindin- $\mathrm{D}_{28 \mathrm{~K}}$ expression in the striatal matrix. J Comp Neurol 320:304 322.

Liu F-C, Graybiel AM (1992b) Transient calbindin- $\mathrm{D}_{28 \mathrm{~K}}$-positive systems in the telencephalon: ganglionic eminence, developing striatum and cerebral cortex. J Neurosci 12:674-690.

Liu F-C, Dunnett SB, Robertson HA, Graybiel AM (1991) Intrastriatal grafts derived from fetal striatal primordia. III. Induction of modular patterns of Fos-like immunoreactivity by cocaine. Exp Brain Res 85 : 501-506.

Liu F-C, Takahashi H, McKay RDG, Graybiel AM (1993) Dopaminergic regulation of gene expression in striatal slice culture. Soc Neurosci Abstr 19:132.

Lombroso PJ, Murdoch G, Lerner M (1991) Molecular characterization of a protein-tyrosine-phosphatase enriched in striatum. Proc Natl Acad Sci USA 88:7242-7246.

Lombroso PJ, Naegele JR, Sharma E, Lerner M (1993) A protein tyrosine phosphatase expressed within dopaminoceptive neurons of the basal ganglia and related structures. J Neurosci 13:3064-3074.

McCobb DP, Haydon PG, Kater SB (1988) Dopamine and serotonin inhibition of neurite elongation of different identified neurons. J Neurosci Res 19:19-26.

McMillian MK, He XP, Hong JS, Pennypacker KR (1992) Dopamine stimulates $\left[{ }^{3} \mathrm{H}\right]$ phorbol 12,13 -dibutyrate binding in cultured striatal cells. J Neurochem 58:1308-1312.

Moon Edley S, Herkenham M (1984) Comparative development of 
striatal opiate receptors and dopamine revealed by autoradiography and histofluorescence. Brain Res 305:27-42.

Moratalla R, Robertson HA, Graybiel AM (1992) Dynamic regulation of NGFI-A (zif268, egr1) gene expression in the striatum. J Neurosci 12:2609-2622.

Moratalla R, Vickers EA, Robertson HA, Cochran BH, Graybiel AM (1993) Coordinate expression of c-fos and jun B is induced in the rat striatum by cocaine. J Neurosci 13:423-433.

Murrin LC, Ferrer JR (1984) Ontogeny of the rat striatum: correspondence of dopamine terminals, opiate receptors and acetylcholinesterase. Neurosci Lett 47:155-160.

Murrin LC, Zeng W (1989) Dopamine D1 receptor development in the rat striatum: early localization in striosomes. Brain Res 480:170-177.

Nagahama S, Chen YF, Lindheimer MD, Oparil S (1986) Mechanism of the pressor action of LY171555, a specific dopamine D2 receptor agonist, in the conscious rat. J Pharmacol Exp Ther 236:735-742.

Naranjo JR, Mellström B, Achaval M, Sassone-Corsi P (1991) Molecular pathways of pain: fos/jun-mediated activation of a noncanonical AP-1 site in the prodynorphin gene. Neuron 6:607-617.

Nguyen TV, Kosofsky BE, Birnbaum R, Cohen BM, Hyman SE (1992) Differential expression of c-Fos and Zif268 in rat striatum after haloperidol, clozapine, and amphetamine. Proc Natl Acad Sci USA 89: 4270-4274.

Nestler EJ (1992) Molecular mechanisms of drug addiction. J Neurosci 12:2439-2450.

Nielsen EB, Randrup K, Anderson PH (1989) Amphetamine discrimination: effects of dopamine receptor agonists. Eur J Pharmacol 160: 253-262.

O'Brian CA, Roczniak SO, Bramson NH, Baraniak J, Stec WJ, Kaiser ET (1982) A kinetic study of interaction of $\left(R_{p}\right)$ - and $\left(S_{p}\right)$-adenosinc cyclic 3',5'-phosphorothiates with type II bovine cardiac muscle adenosine cyclic 3 ',5'-phosphate dependent protein kinase. Biochemistry $21: 4371-4376$.

Olson L, Seiger A, Fuxe K (1972) Heterogeneity of striatal and limbic dopamine innervation: highly fluorescent islands in developing and adult rats. Brain Res 44:283-288.

Ouimet CC, Miller PE, Hemmings HC Jr, Walaas SI, Greengard P (1984) DARPP-32, a dopamine- and adenosine $3^{\prime}: 5^{\prime}$-monophosphate-regulated phosphoprotein enriched in dopamine-innervated brain regions. III. Immunocytochemical localization. J Neurosci 4:111124.

Ouimet CC, Hemmings HC Jr, Greengard P (1989) ARRP-21, a cyclic AMP-regulated phosphoproteins enriched in dopamine-innervated brain regions. II. Immunocytochemical localization in rat brain. $\mathbf{J}$ Neurosci 9:865-875.

Panula P, Reichardt L, Hervonen H (1979) Observations on the morphology and histochemistry of the rat neostriatum in tissue culture. Neuroscience 4:235-248.

Paul ML, Graybiel AM, David J-C, Robertson HA (1992) D1-like and D2-like dopamine receptors synergistically activate rotation and c-fos expression in the dopamine-depleted striatum in a rat model of Parkinson's disease. J Neurosci 12:3729-3742.

Polli JW, Kincaid RL (1992) Molecular cloning of DNA encoding a calmodulin-dependent phosphodiesterase enriched in the striatum. Proc Natl Acad Sci USA 89:1 1079-11083.

Polli JW, Kincaid RL (1994) Expression of calmodulin-dependent phosphodiesterase isoform (PDE 1B1) correlates with brain regions having extensive dopaminergic innervation. J Neurosci 14:12511261.

Ragsdale CW, Graybiel AM (1983) Butyrylcholinesterase in the dorsal and ventral striatum: observations of histochemical distributions in adult, fetal and neonatal cats. Soc Neurosci Abstr 9:15.

Reinoso B, Undie A, Pimenta A, Levitt P (1993) Dopamine receptor regulation of cerebral cortical neurons developing in vitro. Soc Neurosci Abstr 19:614.

Robertson HA, Peterson MR, Murphy K, Robertson GS (1989) D Dopamine receptor agonists selectively activate striatal c-fos independent of rotational behavior. Brain Res 503:346-349.

Sales N, Martres MP, Bouthenet ML, Schwartz JC (1989) Ontogeny of dopaminergic $\mathrm{D}_{2}$ receptors in the rat nervous system: characterization and detailed autoradiographic mapping with [ ${ }^{125}$ I] iodosulpiride. Neuroscience 28:673-700.
Sassone-Corsi P, Visvader J, Ferland L, Mellon PL, Verma IM (1988) Induction of protooncogene fos transcription through the adenylate cyclase pathway: characterization of a cAMP-responsive element. Genes Dev 2:1529-1538.

Schambra UB, Duncan GE, Breese GK, Fornaretto MG, Caron MG, Fremeau RT Jr (1994) Ontogeny of $D_{14}$ and D2 dopamine receptor subtypes in rat brain using in situ hybridization and receptor binding. Neuroscience 62:65-85.

Segal RA, Takahashi H, McKay RDG (1992) Changes in neurotrophin responsiveness during the development of cerebellar granule neurons. Neuron 9:1041-1052.

Sheng M, Greenberg ME (1990) The regulation and function of c-fos and other immediate early genes in the nervous system. Neuron $4: 477-485$

Sheng M, McFadden G, Greenberg ME (1990) Membrane depolarization and calcium induce $c$-fos transcription via phosphorylation of transcription factor CREB. Neuron 4:571-582.

Sheng M, Thompson MA, Greenberg ME (1991) CREB: a Ca ${ }^{2+}$-regulated transcription factor phosphorylated by calmodulin-dependent kinases. Science 252:1427-1430.

Sibley DR, Monsma FJ Jr, Shen Y (1993) Molecular neurobiology of dopaminergic receptors. In: International review of neurobiology (Bradley RJ, Harris RA, eds), pp 391-415. San Diego: Academic.

Simpson JN, McGinty JF (1994) Forskolin increases phosphorylatedCREB and Fos immunoreactivity in rat striatum. Neuroreport 5:1213-1216.

Sivam SP (1989) Cocaine selectively increases striatonigral dynorphin levels by a dopaminergic mechanism. J Pharmacol Exp Ther 250: $818-824$.

Sonnenberg JL, Rauscher FJ III, Morgan JI, Curran T (1989) Regulation of proenkephalin by fos and jun. Science 246:1622-1625.

Specht LA, Pickel VM, Joh TH, Reis DJ (1981) Light-microscopic immunocytochemical localization of tyrosine hydroxylase in prenatal rat brain. II. Late ontogeny. J Comp Neurol 199:255-276.

Steiner H, Gerfen CR (1993) Cocaine-induced c-fos messenger RNA is inversely related to dynorphin expression in striatum. $\mathrm{J}$ Neurosci 13:5066-5081.

Stoppini L, Buchs P-A, Muller D (1991) A simple method for organotypic cultures of nervous tissue. J Neurosci Methods 37:173-182.

Swarzenski BC, Tang L, Oh YJ, O'Malley KL, Todd RD (1994) Morphogenic potentials of D2, D3 and D4 dopamine receptors revealed in transfected neuronal cell lines. Proc Natl Acad Sci USA 91:649653

Tennyson VM, Barrett RE, Cohen G, Cote L, Heikkila R, Mytilncou C (1972) The developing neostriatum of the rabbit: correlation of fluorescence histochemistry, electron microscopy, endogenous dopamine levels, and $\left[{ }^{3} \mathrm{H}\right]$ dopamine uptake. Brain Res 46:251-285.

van der Kooy D (1984) Developmental relationships between opiate receptors and dopamine in the formation of caudate-putamen patches. Dev Brain Res 14:300-303.

Voorn P, Kalsbeek A, Jorritsma-Byham B, Groenewegen HJ (1988) The pre- and postnatal development of the dopaminergic cell groups in the ventral mesencephalon and the dopaminergic innervation of the striatum of the rat. Neuroscience 25:857-888.

Walaas SI, Greengard P (1984) DARPP-32, a dopamine- and adenosine $3^{\prime}: 5^{\prime}$-monophosphate-regulated phosphoprotein enriched in dopamine-innervated brain regions. I. Regional and cellular distribution in the rat brain. J Neurosci 4:84-98.

Walaas SI, Cala S, Greengard P (1989) Localization of ARPP-90, a major 90 kiloDalton basal ganglion-enriched substrate for cyclic AMP-dependent protein kinase, in striatonigral neurons in the rat brain. Mol Brain Res 5:149-157.

Yan C, Bentley JK, Sonnenburg WK, Beavo JA (1994) Differential expression of the $61 \mathrm{kDa}$ and $63 \mathrm{kDa}$ calmodulin-dependent phosphodiesterases in the mouse brain. J Neurosci 14:973-984.

Young ST, Porrino LJ, Iadarola MJ (1991) Cocaine induces striatal c-Fos-immunoreactive proteins via dopaminergic D1 receptors. Proc Natl Acad Sci USA 88:1291-1295.

Zhang WQ, Pennypacker H, Ye H, Merchenthaler II, Grimes L, Iadarola MJ, Hong JS (1992) A $35 \mathrm{kDa}$ Fos-related antigen is co-localized with substance $P$ and dynorphin in striatal neurons. Brain Res 577 : 312-317. 